\title{
Extremely high diversity of sulfate minerals in caves of the Irazú Volcano (Costa Rica) related to crater lake and fumarolic activity
}

\author{
Andrés Ulloa ${ }^{1,2^{*}}$, Fernando Gázquez ${ }^{3}$, Aurelio Sanz-Arranz ${ }^{4}$, Jesús Medina ${ }^{4}$, Fernando \\ Rull $^{4}$, José Maria Calaforra ${ }^{5}$, Guillermo E. Alvarado ${ }^{1,6}$, María Martínez ${ }^{7}$, Geoffroy Avard ${ }^{7}$, \\ J. Maarten de Moor ${ }^{7}$, and Jo De Waele ${ }^{8}$ \\ ${ }^{1}$ Centro de Investigación en Ciencias Geológicas, Universidad de Costa Rica \\ ${ }^{2}$ Karst Research Institute, University of Nova Gorica, Titov trg 2, SI-6230 Postojna, Slovenia \\ ${ }^{3}$ School of Earth and Environmental Sciences, University of St. Andrews, St Andrews, KY16 9AL, Scotland, UK \\ ${ }^{4}$ Unidad Asociada UVA-CSIC al Centro de Astrobiología, University of Valladolid, Parque tecnológico Boecillo, 47151 Valladolid, Spain \\ ${ }^{5}$ Department of Hydrogeology and Analytical Chemistry, University of Almeria, Crta. Sacramento, s/n, 04120 La Cañada de San Urbano, Almeria, Spain \\ ${ }^{6}$ Red Sismológica Nacional (RSN: UCR-ICE), Apdo. 214-2060, San Pedro, Costa Rica \\ ${ }^{7}$ Observatorio Vulcanológico y Sismológico de Costa Rica, Universidad Nacional, Heredia, Costa Rica \\ ${ }^{8}$ Department of Biological, Geological and Environmental Sciences, University of Bologna, Via Zamboni, 67, 40126 Bologna, Italy
}

\begin{abstract}
The caves of the Irazú volcano (Costa Rica), became accessible after the partial collapse of the NW sector of the Irazú volcano in 1994, offering the opportunity to investigate active minerogenetic processes in volcanic cave environments. We performed a detailed mineralogical and geochemical study of speleothems in the caves Cueva los Minerales and Cueva Los Mucolitos, both located in the northwest foothills of the main crater. Mineralogical analyses included X-ray diffraction (XRD) and Raman spectroscopy, while geochemical characterization used Energy Dispersive X-ray spectroscopy (EDX) coupled to Scanning Electron Microscopy (SEM). In addition, measurements of environmental parameters in the caves, cave drip water and compilation of geochemical analyses of the Irazú volcanic lake $(\sim 150 \mathrm{~m}$ above the cave level) and fumarole analyses were conducted between 1991 and 2014. We identified forty-eight different mineral phases, mostly rare hydrated sulfates of the alunite, halotrichite, copiapite, kieserite and rozenite groups, thirteen of which are described here as cave minerals for the first time. This includes the first occurrence in cave environments of aplowite, bieberite, boyleite, dietrichite, ferricopiapite, ferrinatrite, lausenite, lishizhenite, magnesiocopiapite, marinellite, pentahydrite, szomolnokite, and wupatkiite. The presence of other new cave minerals such as tolbachite, mercallite, rhomboclase, cyanochroite, and retgersite, is likely but could not be confirmed by various mineralogical techniques. Uplifting of sulfurous gases, water seepage from the Irazú volcanic lake and hydrothermal interactions with the volcanic host rock are responsible for such extreme mineralogical diversity. These findings make the caves of the Irazú volcano a world-type- reference locality for investigations on the formation and assemblage of sulfate minerals and the biogeochemical cycle of sulfur, with potential implications for Astrobiology and Planetary science.
\end{abstract}

Keywords: $\quad$ hydrated sulfates, sulfate speleothems, volcanic caves, crater lake, cave minerogenesis Received 31 March 2018; Revised 22 May 2018; Accepted 3 June 2018

Citation: Ulloa A., Gázquez F., Sanz-Arranz A., Medina J., Rull F., Calaforra J.M., Alvarado G.E., Martínez M., Avard G., de Moor J.M. and De Waele J., 2018. Extremely high diversity of sulfate minerals in caves of the Irazú Volcano (Costa Rica) related to crater lake and fumarolic activity. International Journal of Speleology, 47 (2), 229-246. Tampa, FL (USA) ISSN 0392-6672 https://doi.org/10.5038/1827-806X.47.2.2198

\section{INTRODUCTION}

Although still poorly studied compared to karstic carbonate environments, lava tubes and volcanic caves have drawn the interest of many speleological and mineralogical investigations over the past 20 years (Forti, 1994, 2005, Forti et al., 2003, 2004; Daza \& Bustillo, 2014; Miller et al., 2014, among others).
Increasing attention is being paid to minerogenesis and weathering processes in terrestrial magmatic materials, and in particular to subterranean volcanic environments, as analogues of mineral-forming mechanisms on Mars and other planets (e.g., Morse et al., 2011; Miller et al., 2014; Lalla et al., 2015, 2016). Indeed, volcanic caves host over $40 \%$ of the total number of cave minerals reported to date, whereas 
$10 \%$ of the mineral species found in caves worldwide are limited to subterranean volcanic environments (Hill \& Forti, 1997; Forti, 2005; Onac \& Forti, 2011a).

Silicate minerals (e.g., opal and clay minerals) and carbonate speleothems (predominantly made of calcite and/or aragonite), sometimes derived from biological processes, are relatively common in volcanic caves (Daza \& Bustillo, 2014; Miller et al., 2014). However, sulfates are the main group in terms of mineralogical diversity, representing over $70 \%$ of the different minerals reported from volcanic caves (Hill \& Forti, 1997; Forti, 2005). The five main processes leading to sulfate speleothem precipitation in volcanic caves include: (1) deposition from aerosols, (2) evaporation of $\mathrm{SO}_{4}{ }^{2-}$ rich waters, (3) alteration and weathering (e.g., oxidation of reduced sulfur species), (4) biomediated mineral precipitation, and (5) bat guano mineralization.

Sulfur-rich caves commonly present sulfate speleothems (secondary mineral deposits formed in caves) such as stalactites, stalagmites, and crusts. Less common are geysermites, vent-shaped speleothems with a central hole that continues in the cave floor and are formed by rising thermal fluids (vapor) (Hill \& Forti, 1997 and references therein); rims and blisters, formed in fractures with fumarole vapors influence (Onac \& Forti, 2011b). In some of these sulfur-rich caves [e.g., Cueva de Villa Luz in Mexico, Hose et al. (2000); Frasassi cave in Italy, Jones et al. (2016)] white mucous-like soda straw biofilms hanging from cave walls and known as "snottites" (Hose \& Pisarowicz, 1999) have been reported.
We conducted a detailed mineralogical and geospeleological study of Cueva Los Minerales (CMI) and Cueva Los Mucolitos (CMU), in the Irazú Volcano, Costa Rica (Fig. 1A). This area is characterized by its intense volcanic influence, with relevant $\mathrm{CO}_{2}$ emissions (Galindo et al., 2004; Epiard et al., 2017) and evidence of passive fumarole activity and hydrothermalism (Alvarado et al., 2006). Here, we discuss factors related to minerogenesis, the formation of the caves themselves and their linkage with the hydrothermal system. In addition, we provide measurements of environmental parameters in the cave, hydrochemical analyses of cave infiltration waters, those present in the Irazú volcanic lake and in fumaroles (from 1991 to 2014). Abundant sulfur gases and dissolved sulfur species in the cave water are proposed as being responsible for the precipitation of an unusual diversity of sulfate minerals, many of which are reported here as cave minerals for the first time. The exact ages of the investigated caves are unknown, although access from the surface to these caves exist since December $8^{\text {th }}, 1994$, when a large landslide on the volcano flank occurred. Thus, minerogenetic processes in the caves of the Irazú Volcano can be considered as a recent and ongoing example of sulfate mineral precipitation in the volcanic subterranean environment.

\section{STUDY SITES}

The Costa Rica Volcanic Front is developed parallel to the Middle American Trench that separates the Coco and Caribbean plates. The convergence rate

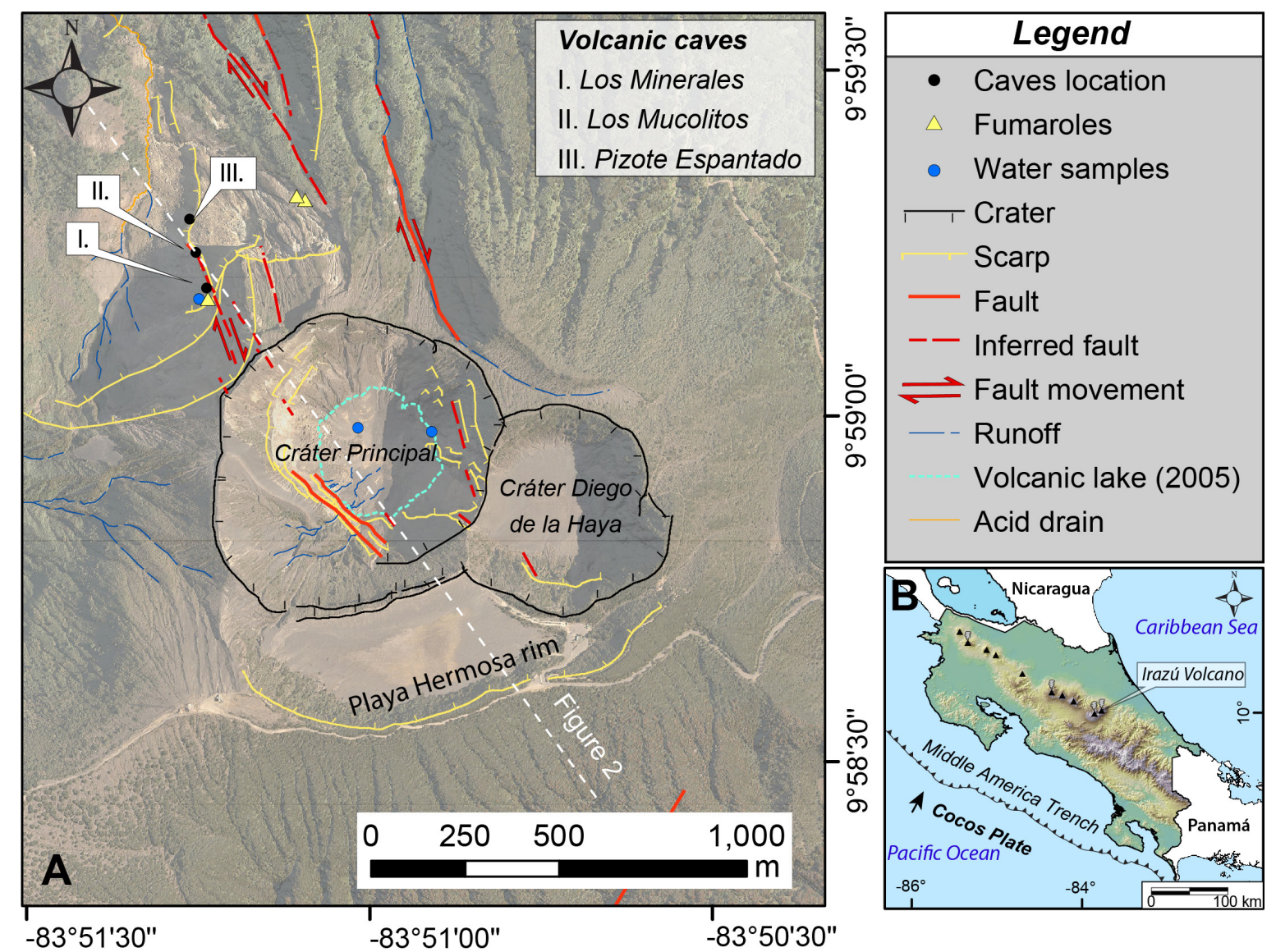

Fig. 1. Caves of Irazú Volcano. A) Summit of Irazú Volcano with location of caves, water samples, and other geological elements (craters, fumaroles, scarps, faults, runoff, previous volcanic lake, and acid drain); B) Location of Irazú Volcano in Costa Rica and volcanic chain context. 
between the subducting Coco Plate and the Caribbean Plate in Costa Rica is close to $\sim 90 \mathrm{~mm} / \mathrm{yr}$ (DeMets, 2001) (Fig. 1B). Upper plate deformation is affected by differences in subducting plate morphology, age, and dip, resulting in different deformation styles in northern and southern Costa Rica (Protti \& Güendel, 1995). The Central Costa Rica Deformed Belt is the onshore expression of the transition of these two deformation styles (Marshall et al., 2000; Montero et al., 2013). It is characterized by shallow seismicity $(<15 \mathrm{~km})$ and a broad array of conjugate northweststriking dextral faults and northeast-striking sinistral faults (Montero et al., 2013).

Irazú Volcano is located on an area of structural weakness dominated by the Atirro-Rio Sucio Fault System. It consists of a $150 \mathrm{~km}$ long northwesttrending zone of dextral strike-slip faults with strong morphotectonic expression (Montero et al., 2013), it presents active seismicity, and it is composed of different active faults (Montero \& Alvarado, 1995; Montero, 2001; Montero et al., 2013).

The two main craters of the Irazu Volcano, the highest volcano in Costa Rica (altitude 3,432 m a.s.1), are located in the 35 by $10 \mathrm{~km}$ wide pull-apart basin comprised between traces of the Eastern and Western Río Sucio Faults (Montero et al., 2013). The Irazú Volcano evolved from Early Pleistocene to present (Alvarado et al., 2006) and is characterized by strombolian and phreatomagmatic activity. According to Alvarado et al. (2006), the earliest historicallyrecorded eruption was in 1723. Subsequent activity took place during the last century, the most recent eruptive phase being in 1963-1965. Geological units in the surroundings of Irazú Volcano are Pleistocene to Holocene in age.

The Irazú summit hosts the Main Crater "Crater Activo" (active 1962-1965). The older crater "Diego de la Haya" is located to the east of the summit. The remaining structure of a composite oldest crater called "Playa Hermosa" together with a prehistoric scoria cone and tuff rings can also still be recognized. Evidence of a debris avalanche can be seen to the northwest of the main crater (Alvarado et al., 2013). An intermittent volcanic lake has been present on "Crater Activo" after the last eruptive period (1965). This lake lasted until March 2013 when it disappeared, but it started forming again in 2017. According to Ramirez et al. (2013), the lake had a variable temperature $\left(16-35^{\circ} \mathrm{C}\right), \mathrm{pH}(3.0-5.85)$ and color over time (red, green, turquoise, mustard). The permeability due to fractures in the "Crater Activo" probably contributed significantly to the volume changes (draining) of the volcanic lake, and the lake-hydrothermal system is probably hydrogeologically connected to the Río Sucio springs, NW of the volcano (Ramirez et al., 2013; Pierre et al., 2015). Intra-crater fumaroles were reported several times for the period 1998-2001 on the Crater Activo (Ramirez et al., 2013).

To the northwest of the "Crater Activo", there is an unstable area with strong hydrothermal alteration associated with the Central Río Sucio Fault. On this area three volcanic caves have been found (Fig. 1A): CMI, CMU, and Pizote Espantado (Ulloa et al., 2013, 2015). The caves were exposed after a debris avalanche in 1994. CMI consists of a big chamber ( 50 $\mathrm{m}$ wide and $27 \mathrm{~m}$ long) with a wide entrance that enables sunlight to reach most parts of the cave. It shows the highest mineralogical and speleothem diversity and thermal anomalies. CMU is a narrow, completely dark cave, approximately $38 \mathrm{~m}$ long and $15 \mathrm{~m}$ deep, in which microbial communities (e.g., snottites, microbial mats) can easily be recognized. Pizote Espantado Cave has not been mapped and sampled, thus was not included in this study.

\section{METHODS}

\section{Survey and sampling}

Since 2011, four surveys for sampling and measuring environmental variables in the caves have been carried out. The caves were surveyed using a laser-distance meter, compass, and clinometer. Cave temperature, humidity (wet bulb/dry bulb), and light intensity were measured with portable thermometer (Kestrel 4500, $\pm 1^{\circ} \mathrm{C}$ ), humidity probe (Kestrel 4500, $\pm 3 \%$ ), and photometer equipment (CEM DT-8820 4-in-1 digital Multifunction Environment Meter). Thermal images were obtained using a thermal camera FLIRSC660. In $\mathrm{CMI}$ and $\mathrm{CMU}$ the $\mathrm{CO}_{2}$ and $\mathrm{H}_{2} \mathrm{~S}$ concentrations at the floor level and in the cave atmosphere were measured with a West System WS0820 flux meter.

Mineral and water sampling in CMI and CMU were conducted in 2011, 2013, and 2014. Representative mineral samples were collected based on their visual appearances (e.g., color, texture) and location in the caves. Different types of speleothems (e.g., stalactites, geysermites, crusts on the walls) were collected, preferably broken specimens to minimize impact on the cave. Water samples for trace element analyses were taken in amber glass $50 \mathrm{ml}$ bottles. Samples for analyses of heavy metals were acidified with $\mathrm{HNO}_{3}$ to a $\mathrm{pH}<2$ to prevent precipitation during storage.

\section{Hydrogeochemical and fumarole gas analyses}

Analyses were carried out following certified procedures (INTE-ISO/IEC17025:2005) at Agrotec Analytical Laboratory (San Jose, Costa Rica). Trace element analyses were measured by inductively coupled plasma optical emission spectrometry (Thermo Trace Jarrel-ash 51- $\imath$ ) (Eaton et al., 1998, Standard Method 3120b). Calibration was conducted using synthetic standards with a relative standard deviation (RSD) of $2 \%$ or better.

In this paper, we used cation and anion analyses of 25 water samples collected by the Instituto Costarricense de Electricidad (ICE) from June 1991 to February 1993 and 17 samples collected by the Observatorio Vulcanológico y Sismológico de Costa Rica (OVSICORI) since March 1999 to December 2010 (Supplementary Table 1). Water samples were collected in two $500 \mathrm{ml}$ bottles. Cation samples were preserved with $5 \mathrm{~N} \mathrm{HNO}_{3}$ (one $\mathrm{ml}$ per $100 \mathrm{ml}$ ). The water samples were analysed for cations by Atomic Absorption Spectrophotometer and for anions by titration methods (bicarbonate), spectrophotometric methods and ion chromatography. 
Errors in the determination of the different ions are lower than $10 \%$ in all cases.

The compiled eight fumarole gas analyses for 1991 , 2003, 2006m and 2007 (Table 1), were sampled by ICE and OVSICORI using bottles under vacuum and partially filled with $4 \mathrm{~N} \mathrm{NaOH}$ (Giggenbach, 1975). The caustic solution was used for the analyses of $\mathrm{F}^{-}$and $\mathrm{Cl}^{-}$by ion chromatography and $\mathrm{SO}_{2}$ as $\mathrm{SO}_{4}{ }^{2-}$ after oxidation with $\mathrm{H}_{2} \mathrm{O}_{2}$, by ion chromatography.

\section{Mineralogical analyses}

Raman spectroscopy

Micro-Raman and FT-Raman analyses were carried out at the Unidad Asociada UVA-CSIC of Centro de Astrobiologia, University of Valladolid (Spain). MicroRaman was useful to analyze particular parts of the samples at microscale, based on different colors and textures. A total of 134 micro-Raman spectra were performed in different mineral facies. The excitation

Table 1. Historical fumarole analyses in Irazú Volcano.

\begin{tabular}{|c|c|c|c|c|c|c|c|}
\hline Date & $\mathbf{p H}$ & Temp $\left({ }^{\circ} \mathrm{C}\right)$ & Conductivity $(\mu \mathrm{S} / \mathrm{cm})$ & Salinity (g/L) & $F^{-}(\mathrm{mg} / 1)$ & $\mathrm{Cl}^{-}$(mg/1) & $\mathrm{SO}_{4}^{2-}(\mathrm{mg} / 1)$ \\
\hline $7 / 17 / 1991$ & 2.35 & & & & 1.08 & 1.06 & 503 \\
\hline $5 / 27 / 2003$ & & 88 & & & 0.048 & 2.673 & 42.116 \\
\hline $6 / 12 / 2003$ & & 88 & & & 0.39 & 8.535 & 496.798 \\
\hline $10 / 13 / 2006$ & & & & & n.a. & 1.791 & n.a. \\
\hline $12 / 13 / 2006$ & 2.88 & 87 & 648 & 0.1 & & & \\
\hline $2 / 4 / 2007$ & & & & & 2.235 & 2.173 & 99.224 \\
\hline $5 / 5 / 2007$ & & & & & 2.863 & 86.589 & 57.761 \\
\hline $5 / 15 / 2007$ & 2.41 & 83 & 1854 & 0.8 & 5.525 & 15.214 & 190.662 \\
\hline Maximum & 2.88 & 88 & 1854 & 0.8 & 5.525 & 86.589 & 503 \\
\hline Mean & 2.55 & 86.5 & 1251 & 0.45 & 2.023 & 16.862 & 231.594 \\
\hline Minimum & 2.35 & 83 & 648 & 0.1 & 0.048 & 1.06 & 42.116 \\
\hline
\end{tabular}

source was a Laser Research Electro-Optics (REO) working at $632.8 \mathrm{~nm}$. The KOSI HoloSpec f/1.8i spectrometer from Kaiser Optical covered a spectral range of $150-3800 \mathrm{~cm}^{-1}$ and a spectral resolution of 5 $\mathrm{cm}^{-1}$, while the CCD (charge coupled device) employed was a DV420A-OE-130 model from Andor. The Raman head used was KOSI MKII, HFPH-FC-S-632.8 model from Kaiser Optical Systems coupled by optical fiber to a Nikon Eclipse E600 microscope, which in turn was attached to a JVC TK-C1381EG videocamera for visual analysis and precise control of the measured spots. Two objectives were used, 50x and 100x allowing microanalyses of 37 and $15 \mu \mathrm{m}$ diameter spots, respectively. The laser power on the sample was maintained around $2 \mathrm{~mW}$ to ensure no thermal damage occurred to the samples. Typical integration time for spectral acquisition was $10 \mathrm{~s}$ and 10 accumulations were done. The sample was manually scanned, while the height of focus was varied in order to optimize the intensity of the spectra signals.

In addition, 53 powdered bulk samples were analyzed using a FT-Raman Bruker instrument (model RFS100/S). The coherent laser was a Compass 1064-500 model (Nd:YAG, $1064 \mathrm{~nm}, 500 \mathrm{~mW})$. The CCD Bruker used was a D418-T model, operating in the range 851-1695 $\mathrm{nm}$. The spot diameter was 100 micrometers, using a spectrometer aperture of $7 \mathrm{~mm}$ and a scanning velocity of $7.5 \mathrm{KHz}$. Spectral resolution was $4 \mathrm{~cm}^{-1}$.

The spectra were compared with the RRUFF Raman mineralogical database (http:/ / rruff.info/) for most of the analyses using CrystalSleuth software (Laetsch \& Downs, 2006). Spectra that did not match any in the database were not included in the list and might be related to mineral mixtures or unknown minerals. The comparison spectrum, percentage of match, Raman peaks, integration time and respective number of accumulation are reported in Supplementary Table 2 for micro-Raman analyses and Supplementary Table 3 for FT-Raman.

\section{$X$-Ray diffraction}

$\mathrm{X}$-ray diffraction analyses were carried out at the Unidad Asociada UVA-CSIC of Centro de Astrobiologia, University of Valladolid (Spain). A total of 53 powdered samples were analyzed (Supplementary Table 4) using a Philips PW1710 diffractometer, with a $\mathrm{Cu}$ anode (CuKa, $\lambda=0.154 \mathrm{~nm}$ ) and graphite monochromator. A Ni filter and Al sample holders were utilized. Tension and current produced by the generator were $40 \mathrm{kV}$ and $30 \mathrm{~mA}$ respectively, for all analyses. The analysis used the $2 \theta$ scanning method, using 0.400 seconds per step and within the angular limits of 5 to $70^{\circ}$.

\section{Elemental composition and microphotographies}

Energy Dispersive X-ray spectroscopy (EDX) coupled to Scanning Electron Microscopy (SEM) analyses were performed at the Servicios Centrales de Investigación of the University of Almeria (Spain). SEM microphotographs of 26 samples were taken using a HITACHI S-3500 instrument in variable-pressure mode. The elemental chemistry was determined by EDX microprobe at different points with different typology over several grains of the samples, using an Oxford INCA 7210 X-ray detector, with a voltage of $20 \mathrm{kV}$. A total of 96 micro-analyses were performed (Supplementary Table 5). The diameter of the beam was approximately $1 \mu \mathrm{m}$. The limit of detection of this technique enables major elements such as Fe, Mn, O, $\mathrm{Si}, \mathrm{Al}, \mathrm{Ca}, \mathrm{Pb}, \mathrm{Zn}$, and $\mathrm{Ba}$ to be analyzed.

\section{RESULTS}

\section{Geological observations}

The host rock of the caves consists of interbedded pyroclastic rocks, with centimetric to decimetric 
stratification and poorly selected volcanic breccia with angular volcanic clasts associated with pyroclastic density current deposits. Pyroclastic rocks are light grey, white to yellowish color, and in some areas present evidence of silicification. These rocks are normally poorly to moderately compacted or welded and weathering is intense due to harsh volcanic conditions (e.g., high temperature and volcanic gases). The dip direction $\left(318 / 26^{\circ}\right)$ is well defined by the strata where the caves are located, and this plane served as rupture surface of the 1994 debris avalanche. Pyroclastic rocks close to the CMU entrance, displays synthetic and antithetic Ridel shears with subhorizontal striation and dextral motion. This fault corresponds to the Central Río Sucio Fault (Montero et al., 2013) and extends to CMI and Crater Principal (Fig. 1A and 2). To the south of the main entrance of CMI, there is a sector with evidence of runoff watermarks and mud deposits.

\section{Hydrogeochemistry}

Evidence for multiple aquifers has been reported in Irazú Summit (Alvarado, 1993). An ephemeral upper water level $(\sim 3,170 \mathrm{~m}$ a.s.1.) is associated with the geological contact between recent volcanoclastic deposits and hydrothermally altered rocks. The ephemeral main crater volcanic lake is located between $\sim 3,080$ and $<3,050 \mathrm{~m}$ a.s.1. We provide geochemical

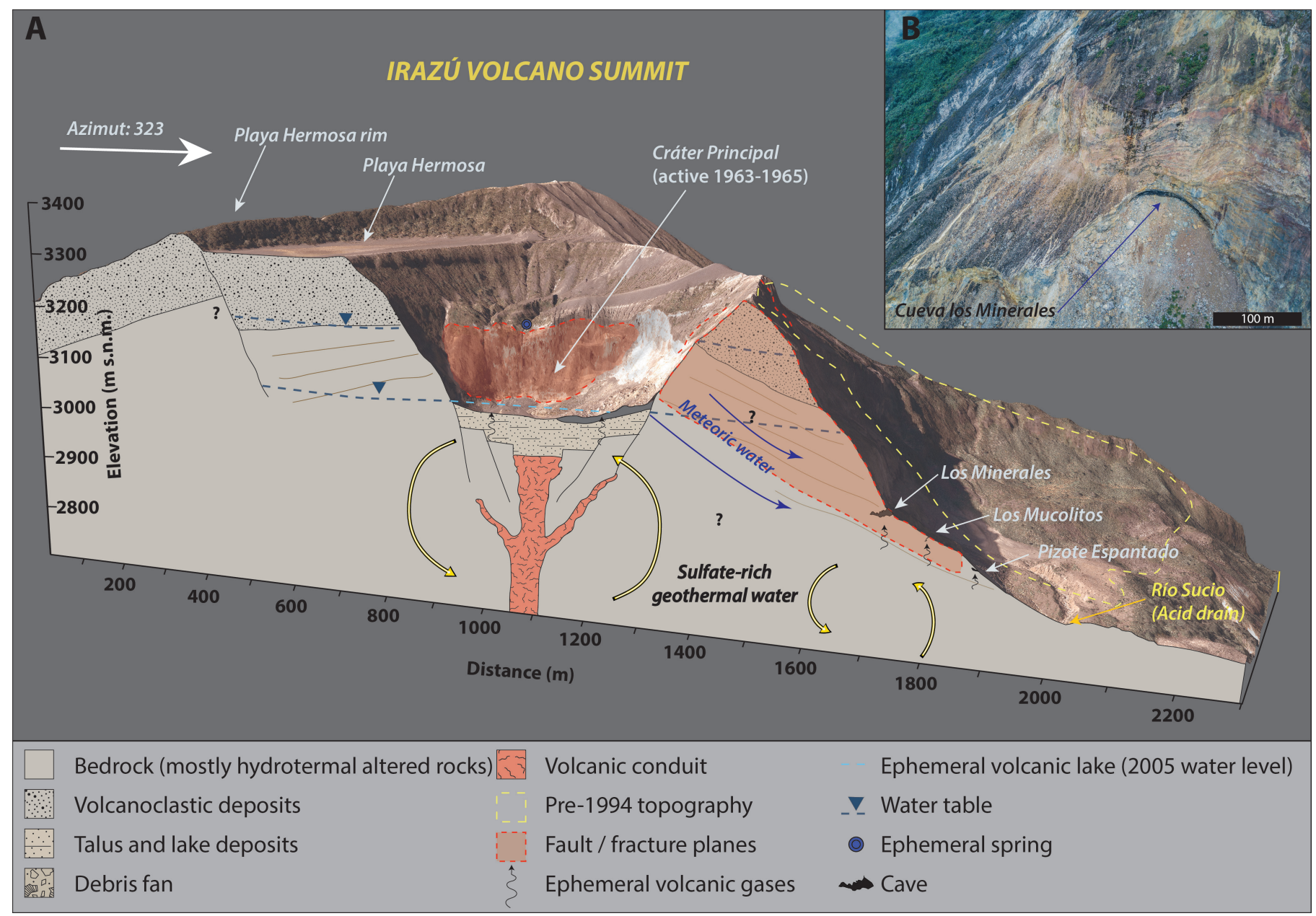

Fig. 2. A) Schematic 3D section of the Irazú Volcano. The main characteristics of the volcano, areas with volcanoclastic deposits, fault locations, and the assumed water table are shown. Meteoric water and volcanic gases also interact with the caves; B) Aerial photo of the entrance of CMI (Photography taken by Cusuko Fotografía in 2017).

water analyses from 1991 to 2010 for the lake waters (Supplementary Table 1). This volcanic lake has undergone important changes in physico-chemical conditions over time. For example, $\mathrm{pH}$ values range from very acid (pH 2.85 in November 1991) to alkaline conditions ( $\mathrm{pH} 8.43$ in March 2005) and temperatures registered a maximum of $93^{\circ} \mathrm{C}$ (July 1993), although the "normal range" is between 14 and $30^{\circ} \mathrm{C}$ (Fig. 3A). The Irazú lake analyses show relatively high content in sulfates $\left(\mathrm{SO}_{4}{ }^{2-}\right)$, with values over $2,500 \mathrm{ppm}$ in 1991-1999 and 2,219 ppm on average for the entire period of this study. Chlorine increases with the sulfates and presents maximum values of $1,020 \mathrm{ppm}$ (in April 1992) and average value of 420 ppm (Fig. 3B). A single infiltration water analysis, which likely comes from volcanic lake seepage waters, was performed in 2013 for selected elements (Fig. 3C). The existence of a deeper aquifer is suggested (Alvarado et al., 2006) associated with phreatomagmatic eruptions and the hydrothermal system in the area. This deeper aquifer could be the source of sulfate-rich water and also one brownish-yellow drain (possibly acidic) close to the base of the cliff (at $\sim 2,825 \mathrm{~m}$ a.s.1.) could be associated with the upwelling of these deeper waters.

\section{Chemical fumarole gas composition}

Fumaroles are located $\sim 300 \mathrm{~m}$ northeast of the cave area (Fig. 1) and ranged in temperature from 83 to $88^{\circ} \mathrm{C}$ and $\mathrm{pH}$ from 2.35 to 2.88 . Table 1 displays the chemical composition of main fumarole components 


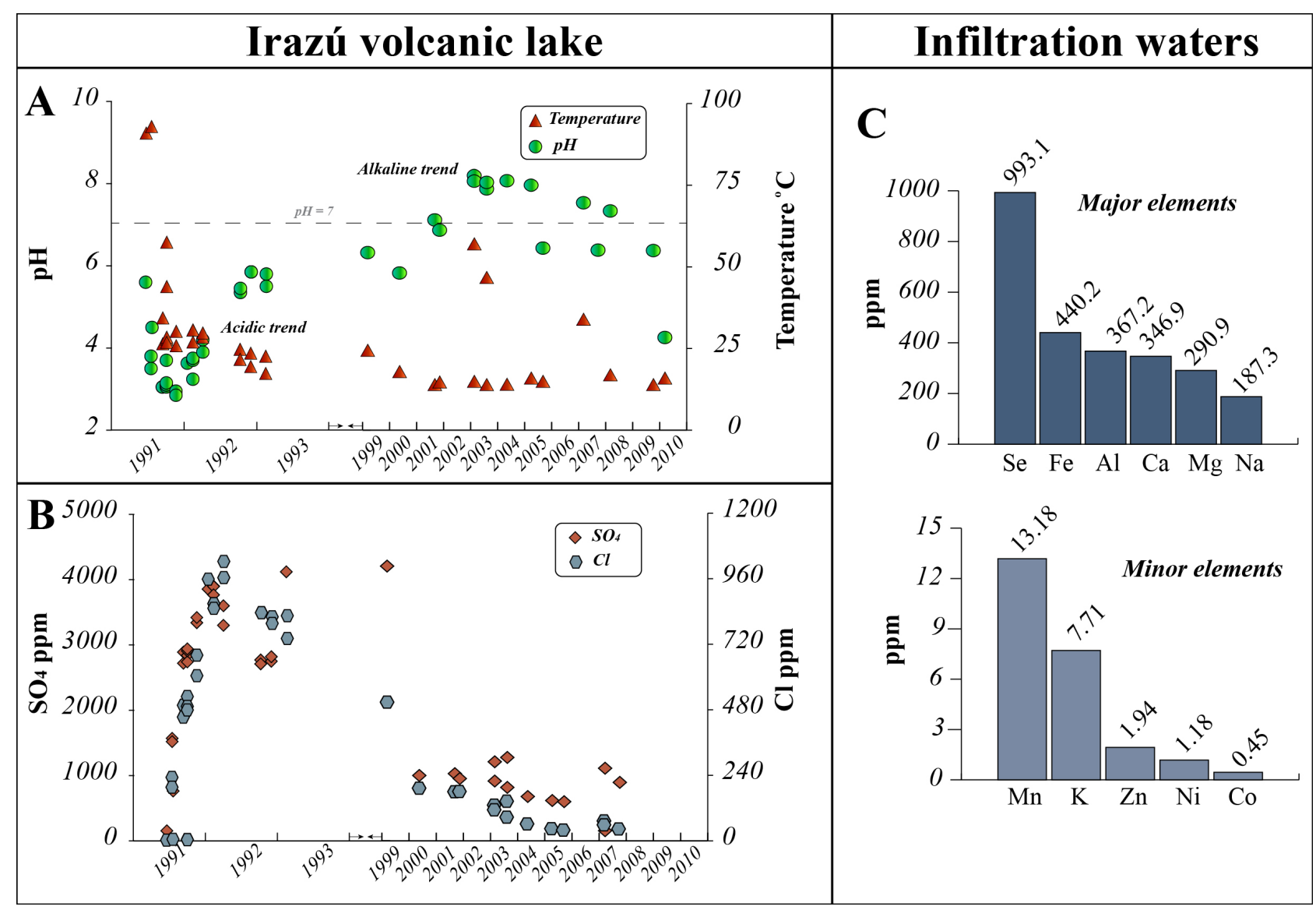

Fig. 3. Hydrogeochemical data. A) Environmental parameters of Irazú lake from 1991 to 2010, showing changes on pH and temperature;

B) Chemical concentration of $\mathrm{SO}_{4}$ and $\mathrm{Cl}$ between 1991 and 2010; C) Infiltration waters in the entrance of the cave of selected elements.

$\left(\mathrm{F}^{-}, \mathrm{Cl}^{-}\right.$, and $\left.\mathrm{SO}_{4}{ }^{2-}\right)$, conducted between 1991 and 2007. The main analyzed component is $\mathrm{SO}_{4}{ }^{2-}$, whose concentrations ranged from 42 to $503 \mathrm{mg} / 1$.

\section{Environmental cave parameters}

CMI presents a wide entrance $\sim 50 \mathrm{~m}$ (Fig. 4A), with a main chamber developing $27 \mathrm{~m}$ from the cave entrance to the end of the cave and approximately $40 \mathrm{~m}$ wide, whereas Sala de los Cristales Verdes is $10 \mathrm{~m}$ wide and presents green stalactites (Fig. 4B). Due to the cave morphology (Fig. 5A), the cave is exposed to sunlight ( $>1.32$ lux during the day), because of the very large cave entrance. Temperature in the cave ranges from 9 to $16{ }^{\circ} \mathrm{C}$ in the main chamber. Thermal map (Fig. 5B) was drawn showing the highest temperatures (28$30^{\circ} \mathrm{C}$ ) close to the north wall fissures (where important sulfate crusts are located) and some unmapped areas close to Sala de los Cristales Verdes show temperatures over $40^{\circ} \mathrm{C}$. The southern part of the main chamber presents the highest elevation and acts as a hot air trap, with temperatures between $30-32^{\circ} \mathrm{C}$. Lower mineral diversity was found in this section of the cave. Based on 2013 field trip measurements, the relative humidity in CMI varies from $74.2 \%$ (close to entrance) to $92.4 \%$ (inner area of the main chamber). $\mathrm{CO}_{2}$ concentrations up to 950 ppm were measured; $\mathrm{H}_{2} \mathrm{~S}$ was $29 \mathrm{ppm}$ and $\mathrm{SO}_{2}$ and $\mathrm{H}_{2}$ were below detection limits.

CMU is smaller in volume, the entrance is small $(\sim 50 \mathrm{~cm})$ and is developed in a collapsed area, $38.2 \mathrm{~m}$ long and $14.6 \mathrm{~m}$ deep. This cave showed temperatures ranging between 16 and $18^{\circ} \mathrm{C}$ and relative humidity of $96.8 \%$ in 2013 . Unlike CMI, this cave is totally dark.
Infiltration water is evident in both caves, and drip points are generally associated with active microbial mats (snottites). The $\mathrm{pH}$ of these drips ranged from 1.00 to 2.61 .

\section{Mineralogy, speleothems and elemental composition}

We identified 48 different minerals in CMI (45) and CMU (6) (Table 2). This includes 19 new cave minerals, of which 14 are referred to as "confirmed"

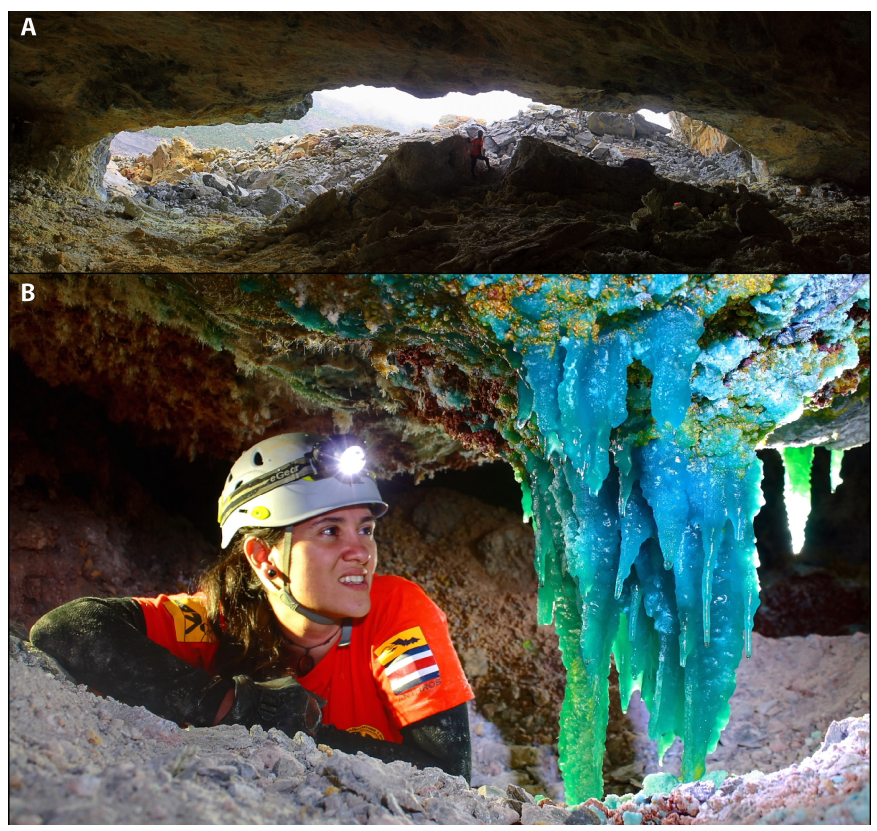

Fig. 4. A) Photography of the cave entrance in CMI; B) szomonolkite stalactite in Sala de los Cristales Verdes (Photographs taken by Victor Carvajal in 2011). 


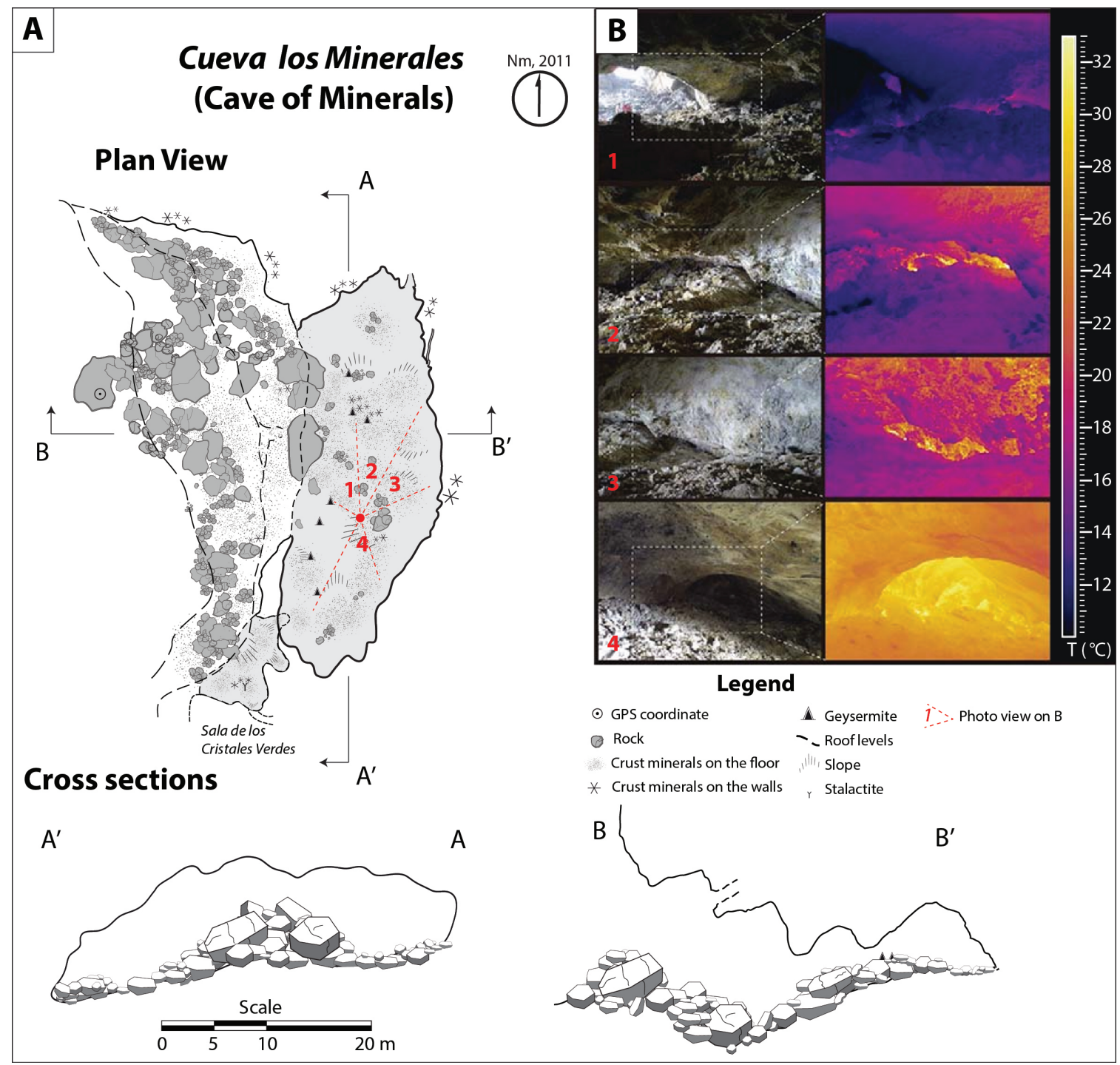

Fig. 5. A) Cave map of CMI, showing the morphology and mineral distribution; B) Thermal mapping of the cave.

(i.e., clearly confirmed by XRD and/or Raman), and also the possible presence of 5 minerals, referred to as "possible" (i.e., low-quality spectra or difficult to distinguish from other mineral phases). Some new cave minerals (aplowite, boyleite, ferrinatrite, magnesiocopiapite and wupatkiite) were previously reported for CMI (Ulloa et al., 2013). Most of them are sulfates, sub-classified with Dana classification in: Anhydrous Acid and Sulfates (3), Anhydrous Sulfates containing Hydroxyl or Halogen (3), Hydrated Acid and Sulfates (33) and Hydrated Sulfates containing Hydroxyl or Halogen (4). Other mineral groups, such as oxides (1), phyllosilicates (3), native elements (1), and halides (1) have also been detected (Fig. 6). Most of the minerals reported in this study by Raman techniques present a percentage of match with the reference spectra from RUFF Database generally $>85 \%$.

\section{Sulfates}

Sulfates were the most common mineral group in the caves of the Irazú Volcano $191.5 \%$ of the total diversity). Most of the identified sulfates correspond to hydrated acid and sulfates (33). Also, sulfates belonging to hydrated sulfates containing hydroxyl or halogen (4), anhydrous acid and sulfates (3), anhydrous sulfates containing hydroxyl or halogen (3) have been detected (Fig. 6).
Anhydrous acid and sulfates

Minerals of this group are present only in CMI. Anglesite has been found forming part of crusts on the walls, floor, and roof of the cave. Under binocular microscope, anglesite shows transparent to green or turquoise green crystals, botryoidal masses or needles and was detected by micro-Raman. Anhydrite has been identified by XRD in two different samples from crusts and stalactites, in association with native sulfur (Fig. 7A and B). The presence of mercallite is possible, although it relies on a single Raman spectrum.

Anhydrous sulfates containing hydroxyl or halogen

Jarosite has been found only in CMU, whereas natroalunite and natrojarosite are present in both caves. These minerals are predominantly yellow in color, and occur on the walls of the caves. Jarosite in CMU was associated with gypsum in an area of acid dripping $(\mathrm{pH}<2)$. Identification by Raman spectroscopy has been confirmed by XRD for all the samples.

\section{Hydrated acid and sulfates}

This group comprises 28 minerals considered as "confirmed" and 5 minerals which presence is "possible" (Table 2). All of these minerals were found in CMI, except for gypsum that is also present in 


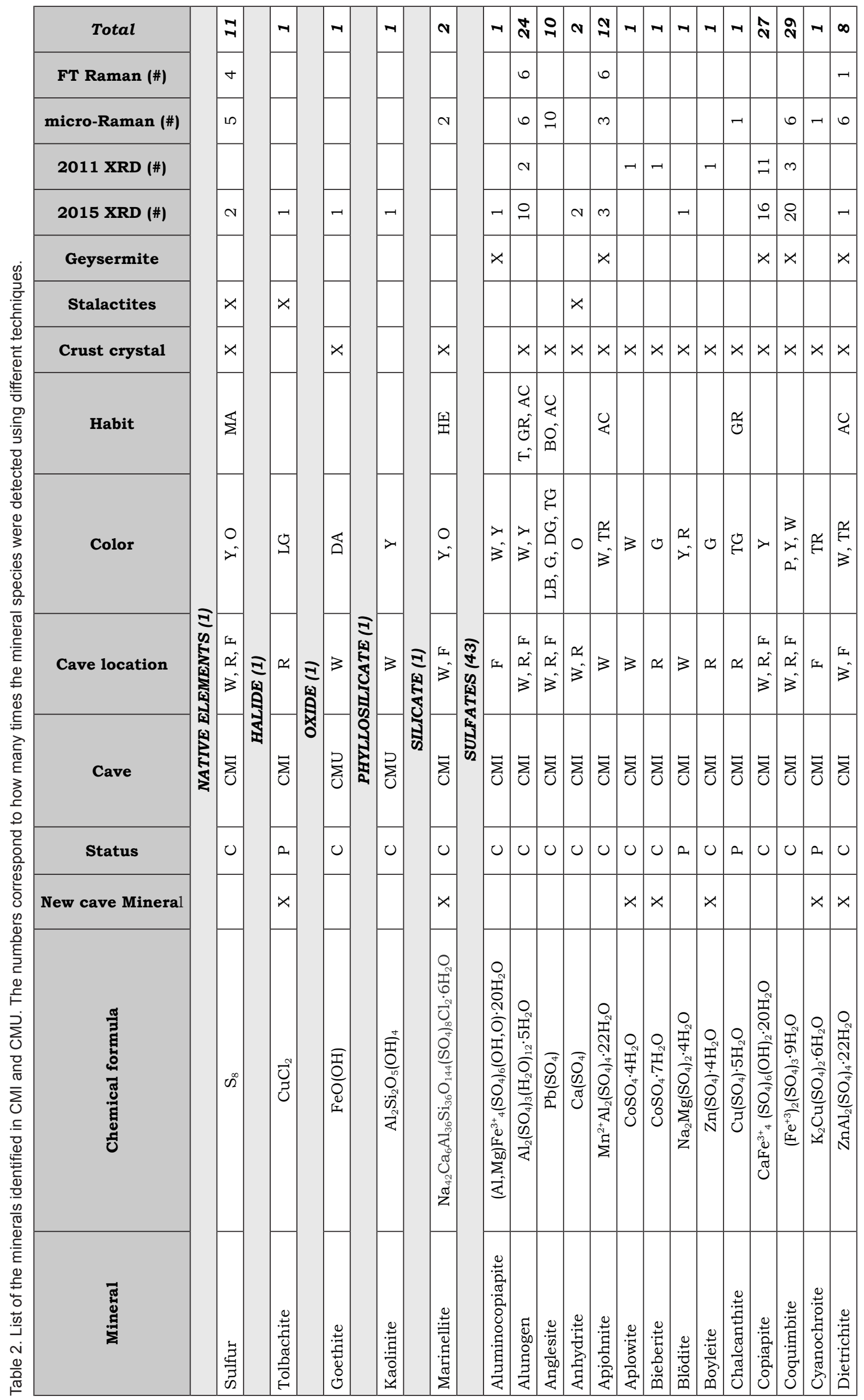




\begin{tabular}{|c|c|c|c|c|c|c|c|c|c|c|c|c|c|c|c|c|c|c|c|c|c|c|c|c|c|c|c|c|c|}
\hline $\boldsymbol{r}$ & $\mid \begin{array}{l}0 \\
-1\end{array}$ & $\infty 7$ & $\bar{z}$ & ¿े & $m$ & is & $m$ & $a$ & -1 & $m$ & no & $\stackrel{10}{-1}$ & -1 & $a$ & + & 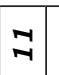 & -1 & 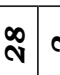 & v & -1 & $\mathcal{N}$ & 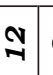 & v & N & O) & \pm & $\begin{array}{c}3 \\
-1\end{array}$ & $\mathbf{I}$ & \\
\hline & -1 & & $\circ 1$ & is & & & & $\mathrm{N}$ & & -1 & & 0 & & & & $\infty$ & & 0 & & & m. & -1 & & & $\neg$ & $\sigma$ & & & 0 \\
\hline & $\stackrel{m}{\rightarrow}$ & & $\wedge$ & 0 & & $\rightarrow$ & & $\wedge$ & & & & $a$ & $\neg$ & $\infty$ & & -1 & & ब & $\mathrm{N}$ & - & $\stackrel{ }{-}$ & & & & & + & $\sigma$ & & \\
\hline-1 & & -1 & + & + & -1 & & & & & -1 & $m$ & & & & & & & $\mathrm{~N}$ & & & N & 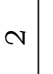 & & $\neg$ & $\neg$ & -1 & & s & \\
\hline & N & 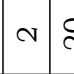 & $\stackrel{\curvearrowright}{\curvearrowright}$ & a & N & 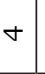 & $m$ & & $\neg$ & -1 & $\sim$ & & & $\neg$ & $\sigma$ & $\wedge$ & $\rightarrow$ & $\exists$ & & & $\wedge$ & $a$ & $\mathrm{~N}$ & $\neg$ & $\infty$ & in. & + & 6 & \\
\hline & $x$ & & & $x$ & & & $x$ & & & $x$ & & & & & & & & $\rtimes$ & & & & & & & & & & $x$ & \\
\hline & & & $x$ & & & & & & & & $x$ & & & & & & & & & & $x$ & $\rtimes$ & & & $x$ & & $x$ & & \\
\hline$x$ & $x$ & $x \mid>$ & $\rtimes>$ & $x$ & $x$ & $x$ & $\rtimes$ & $x$ & $\rtimes$ & $x$ & $x$ & $x$ & $x$ & $x$ & $x$ & $x$ & $x$ & $x>$ & $x=$ & $x$ & $x$ & $x$ & $\rtimes$ & $x$ & $x$ & $x$ & $x$ & $x$ & \\
\hline & & & $\mathrm{H}$ & 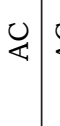 & 尊 & & & 4 & & & & 8 & 4 & 4 & & & & 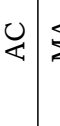 & 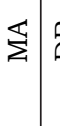 & 崩; & 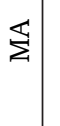 & & & 4 & & & 管 & 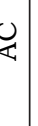 & 5 \\
\hline 3 & $\mid \begin{array}{l}\vec{y} \\
\vec{\nu}\end{array}$ & $\left|\begin{array}{l}0 \\
\hat{\beta}^{\prime}\end{array}\right|$ & $\begin{array}{l}\alpha \\
3 \\
3\end{array}$ & $\begin{array}{l}\alpha \\
3 \\
3\end{array}$ & & & 3 & $\begin{array}{l}7 \\
0 \\
0 \\
3\end{array}$ & 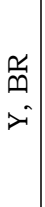 & $\succ$ & 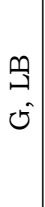 & $\begin{array}{l}\frac{\alpha}{H} \\
3 \\
3\end{array}$ & 3 & $\begin{array}{l}\vec{y} \\
\vec{\lambda}\end{array}$ & & $\succ$ & 3 & 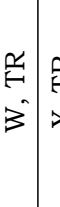 & 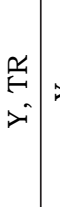 & $>$ & 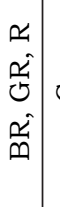 & ك & 0 & $\begin{array}{l}2 \\
3 \\
3\end{array}$ & & 3 & $\vec{m}$ & & 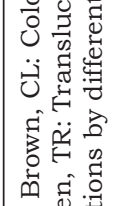 \\
\hline I & $\mid \begin{array}{c}1 \\
\alpha \\
3 \\
3\end{array}$ & 盾 & $\begin{array}{l}5 \\
2 \\
2 \\
3\end{array}$ & \begin{tabular}{l}
\multicolumn{1}{l}{} \\
3
\end{tabular} & $\begin{array}{l}5 \\
3 \\
3\end{array}$ & $\begin{array}{l}x \\
3 \\
3\end{array}$ & 工 & $\begin{array}{l}1 \\
\Omega \\
3\end{array}$ & 3 & $\begin{array}{l}5 \\
3 \\
3\end{array}$ & $\begin{array}{l}1 \\
\Omega \\
3 \\
3\end{array}$ & $\begin{array}{l}\text { I } \\
3\end{array}$ & I & $\begin{array}{l}5 \\
3 \\
3 \\
3\end{array}$ & $\left|\begin{array}{l}\mid x \\
\tilde{\alpha} \\
3 \\
3\end{array}\right|$ & $\begin{array}{l}\alpha \\
3\end{array}$ & I & 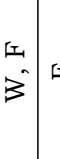 & 江 & 3 & $\begin{array}{l}\Sigma \\
\tilde{2} \\
3\end{array}$ & $\begin{array}{l}x_{1} \\
\hat{2} \\
3 \\
3\end{array}$ & 3 & $\begin{array}{l}5 \\
\approx \\
3 \\
3\end{array}$ & $\begin{array}{l}5 \\
\approx \\
3 \\
3\end{array}$ & $\begin{array}{l}5 \\
\approx \\
3 \\
3\end{array}$ & $\begin{array}{l}\mid \\
\Omega \\
3 \\
3\end{array}$ & $\begin{array}{l}x \\
3 \\
3\end{array}$ & $\begin{array}{c}\overrightarrow{0} \\
\frac{\pi}{m} \\
0\end{array}$ \\
\hline U & $\overrightarrow{0}$ & $\sum_{0}^{1}$ & 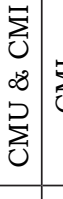 & $\sum_{U}^{E}$ & $\sum_{0}$ & $\sum_{0}^{2}$ & $\vec{z}$ & $\sum_{0}^{E}$ & $\vec{z}$ & $\sum_{0}$ & $\sum_{j}$ & E & ह્ & 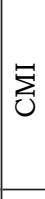 & 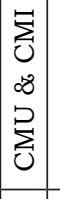 & $\mid$\begin{tabular}{|l}
$\mid$ \\
0 \\
0 \\
$\infty 8$ \\
2 \\
2 \\
0 \\
0
\end{tabular} & $\sum_{j}^{E}$ & $\sum_{0}^{E}$ & $\sum_{0}^{E}$ & $\sum_{0}$ & $\sum_{0}$ & $\sum_{j}^{E}$ & $\sum_{0}^{E}$ & $\sum_{0}$ & $\sum_{0}$ & $\sum_{0}$ & $\sum_{0}^{E}$ & 䓌 & 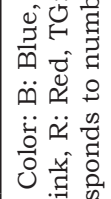 \\
\hline U & 0 & $\begin{array}{llll}0 & 0\end{array}$ & 0 & 0 & 0 & 0 & 0 & 0 & 0 & 0 & 0 & 0 & a & 0 & 0 & 0 & 0 & 0 & $\infty$ & a & 0 & 0 & 0 & 0 & 0 & 0 & 0 & 0 & \\
\hline & $x$ & $x$ & & & & & & $x$ & $x$ & $x$ & & & $x$ & & & & $x$ & & $\rtimes$ & $x$ & & & & & $x$ & & & $x$ & \\
\hline 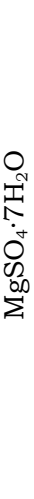 & 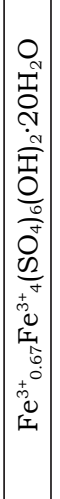 & 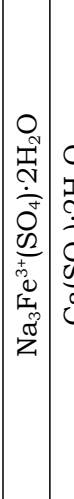 & 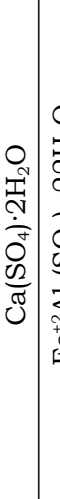 & 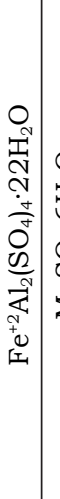 & 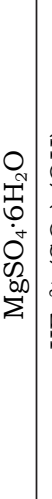 & 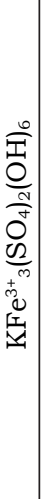 & 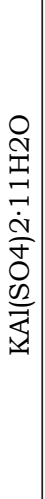 & 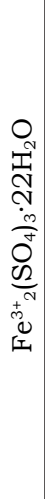 & 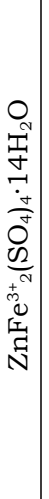 & 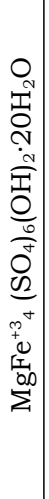 & 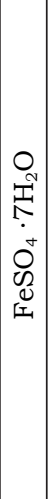 & 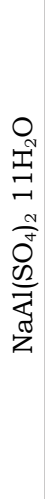 & 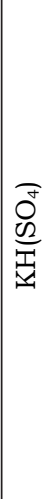 & 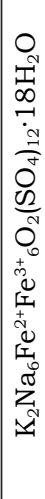 & 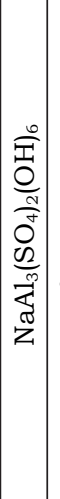 & 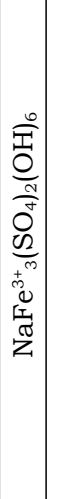 & 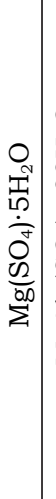 & 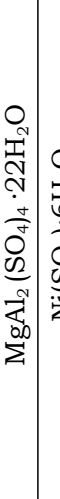 & 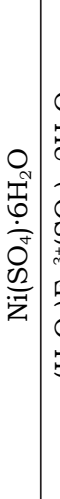 & 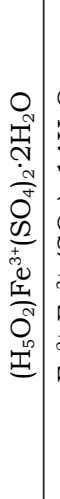 & 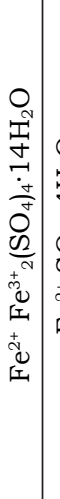 & 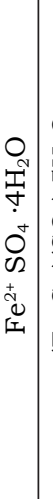 & 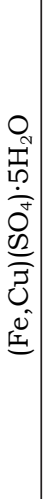 & 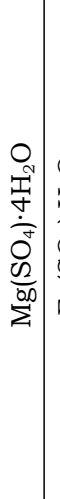 & 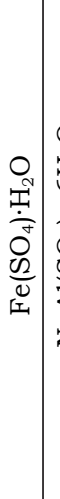 & 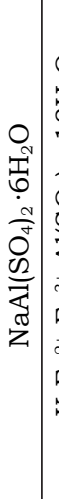 & 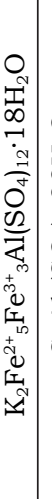 & 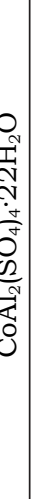 & 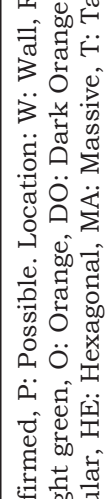 \\
\hline 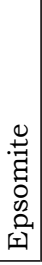 & 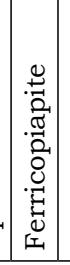 & 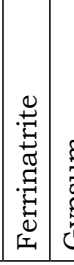 & 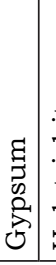 & 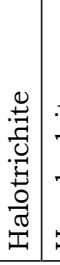 & 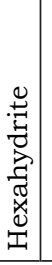 & 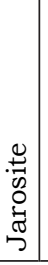 & 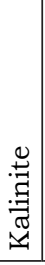 & 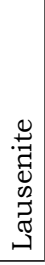 & 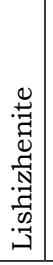 & 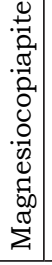 & 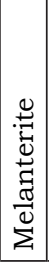 & 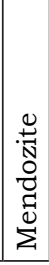 & 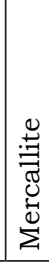 & 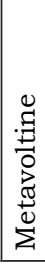 & 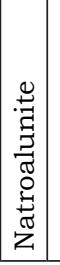 & 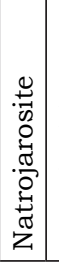 & 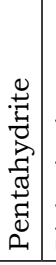 & 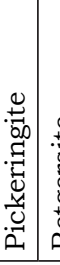 & 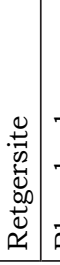 & 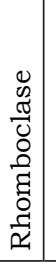 & 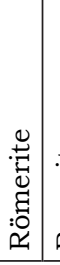 & 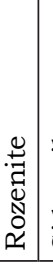 & $\begin{array}{l}\overrightarrow{0} \\
\vec{v} \\
i=2\end{array}$ & 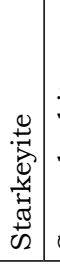 & 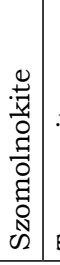 & 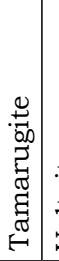 & L & 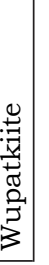 & 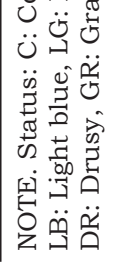 \\
\hline
\end{tabular}


CMU too. Hydrated acid sulfates are sub-classified according to Dana's classification (Mindat, 2018).

Hydrated acid and sulfates with the general formula $(\mathrm{A})_{2}\left(\mathrm{XO}_{4}\right)_{3} \cdot \mathrm{x}\left(\mathrm{H}_{2} \mathrm{O}\right)$ are represented by alunogen, coquimbite (Fig. 8), and lausenite in crusts on the walls, roof, and floor of the cave. Coquimbite was also found in geysermites. Alunogen and coquimbite have been identified by Raman techniques and XRD, lausenite only by FT and micro-Raman. The presence of rhomboclase is suggested by micro-Raman (Fig. 9) and the presence of Fe in EDX analyses.

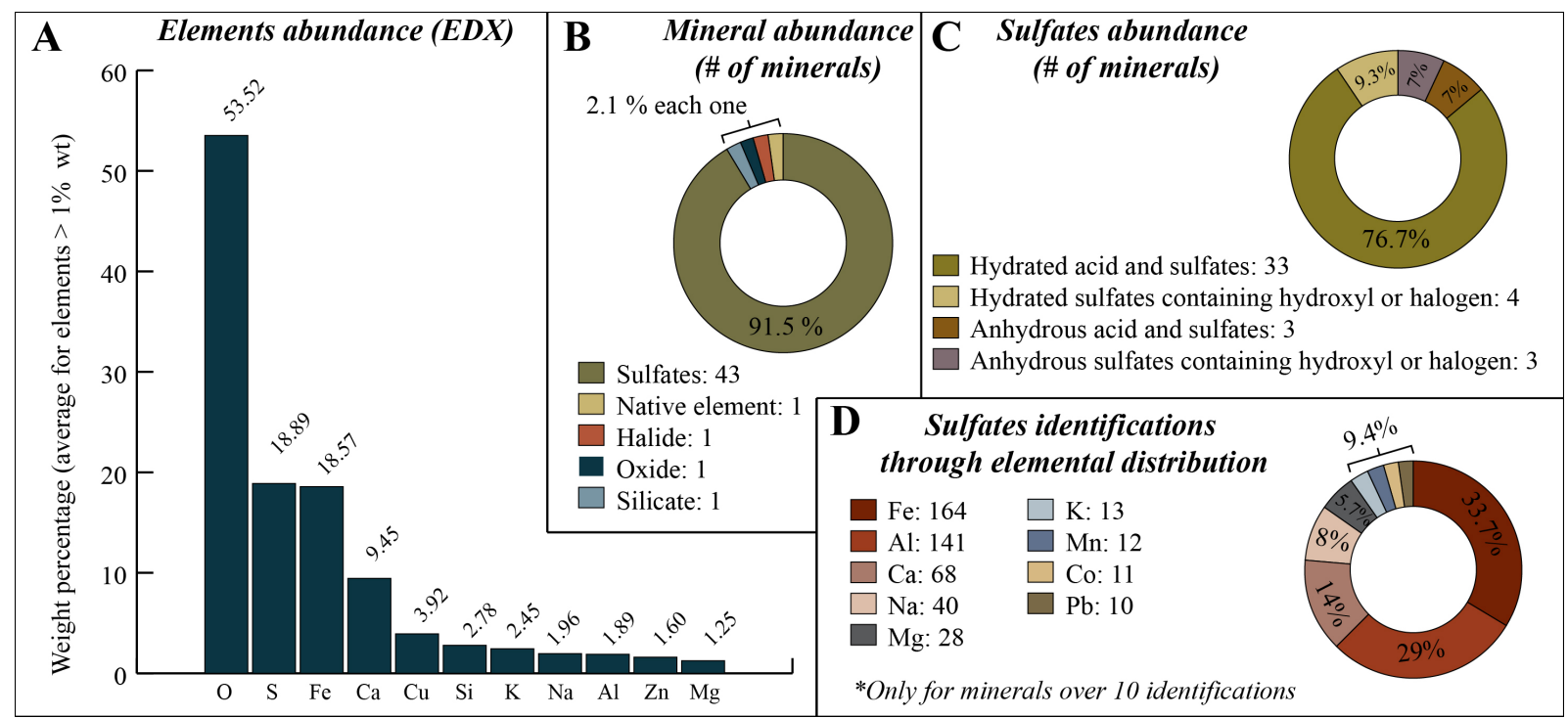

Fig. 6. Abundance of minerals and their main elements in the analyzed caves. A) Mean value of the elemental EDX analyses for elements \% wt; B) mineral groups abundance by number of minerals identified; C) abundance of the sulfate sub-groups;

D) most common elements (excluding $\mathrm{SO}_{4}, \mathrm{OH}$ and $\mathrm{H}_{2} \mathrm{O}$ molecules) for minerals $>10$ identifications, given numbers corresponds to number of identification by mineral.

Hydrated acid and sulfates belonging to the group with general formula $\left(\mathrm{A}^{+}\right)_{2} \mathrm{~B}\left(\mathrm{XO}_{4}\right)_{2} \cdot \mathrm{x}\left(\mathrm{H}_{2} \mathrm{O}\right)$ are represented by the possible presence of blödite (identified by XRD) and cyanochroite (identified by micro-Raman, Fig. 9), whereas ferrinatrite and metavoltine, have been found on walls and roof of the cave.

Some hydrated acid and sulfates with formula $\mathrm{A}(\mathrm{B})_{2}\left(\mathrm{XO}_{4}\right)_{4} \cdot \mathrm{x}\left(\mathrm{H}_{2} \mathrm{O}\right)$ are difficult to differentiate by Raman because of the similarity in the spectra (e.g., apjohnite, dietrichite, halotrichite, pickeringite), with peaks usually at 994 and $975 \mathrm{~cm}^{-1}$, and because they commonly appear in mineral mixtures. However, the combination of XRD-Raman and EDX has made identification possible. Some samples also show a minor peak at $1,025 \mathrm{~cm}^{-1}$ (CR-1C-A and MIM-9A) possible associated with the presence of coquimbite. Minerals from this group, have been found forming part of crusts on the walls and geysermites (Fig. 10A), in some cases associated with ferricopiapite (Fig. 10B), and generally showing acicular habit (Fig. 10C, D). Kalinite, mendozite, and tamarugite, have been detected in several samples.

Hydrated acid and sulfates with formula $\mathrm{A} \mathrm{XO}_{4} \cdot \mathrm{x}\left(\mathrm{H}_{2} \mathrm{O}\right)$ are especially common in these caves. Thirteen species have been found as crust on the walls. Melanterite and rozenite are also part of geysermites, szomolnokite is part of stalactites
(Fig. 11A, B, and C). Gypsum is a very abundant mineral in CMI, covering the north walls of the cave and often associated with some microbial mats. Other new cave minerals from this sub-group are pentahydrite and szomonolkite, both identified by Raman and XRD techniques. Chalcanthite is another possible mineral but was identified only from one micro-Raman analysis; however, it matches $98 \%$ with the reference Raman spectrum $\left(982,609\right.$, and $\left.455 \mathrm{~cm}^{-1}\right)$.

Retgersite is the only nickel sulfate identified by micro-Raman $\left(984,609 \mathrm{~cm}^{-1}\right.$ ) (Fig. 9) that belongs to

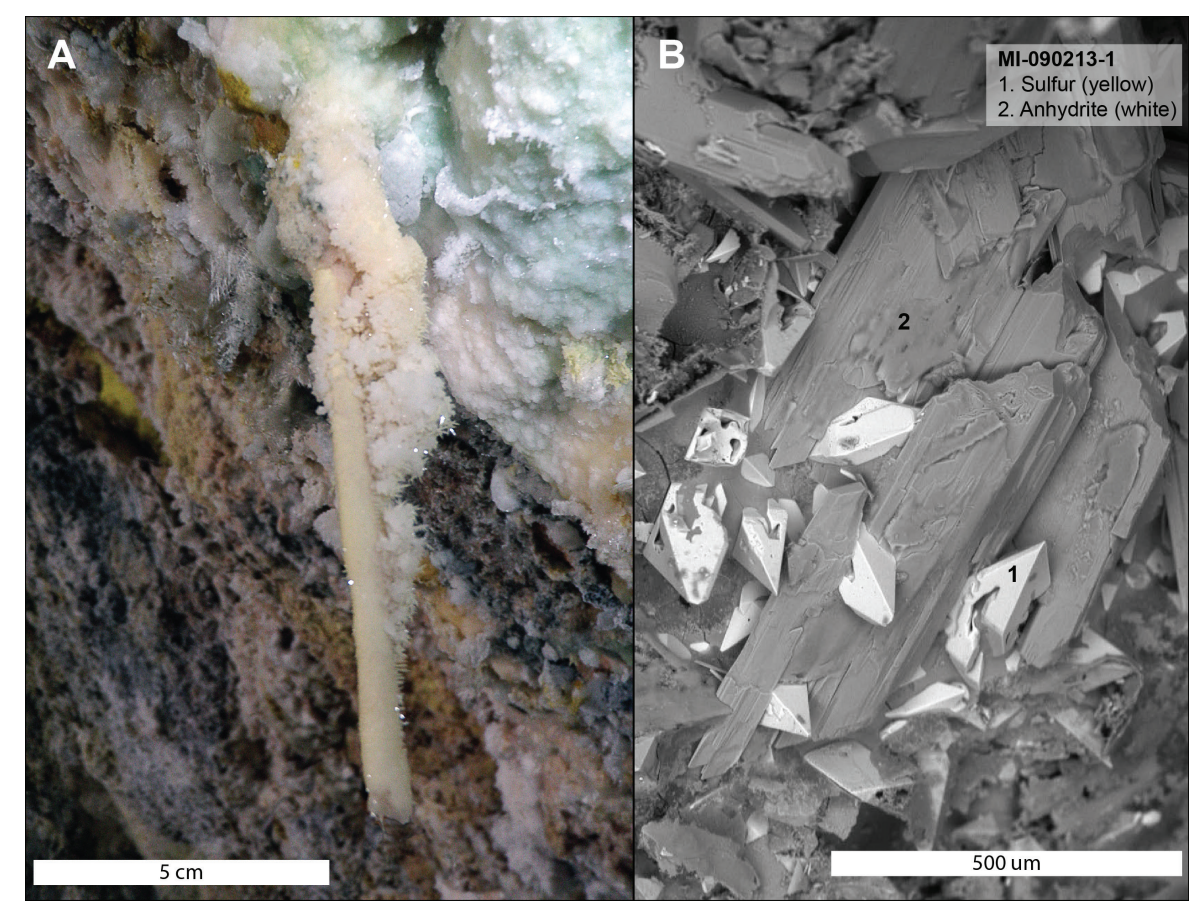

Fig. 7. Some examples of sulfur minerals found in CMI. A) sulfur forming part of a stalactite; B) SEM microphotograph of sulfur detail in association with anhydrite minerals. 


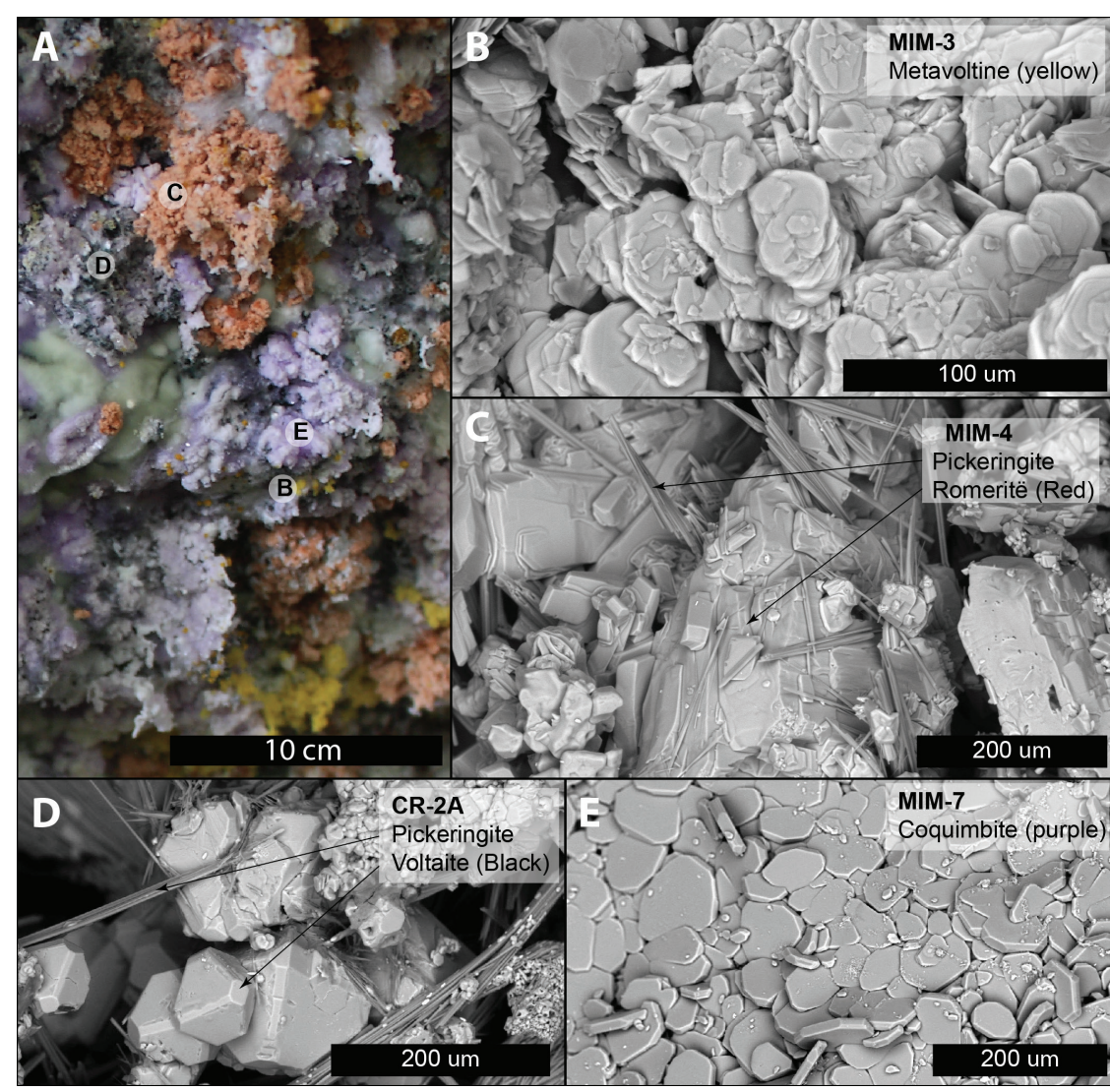

Fig. 8. A) Photograph of crust minerals and location of SEM microphotographs (Photography taken by Victor Carvajal in 2011); B) Metavoltine shows tabular habit and is yellow in color; C) pickeringite is an acicular white mineral, römerite is red in color; D) Pickeringite and voltaite minerals; voltaite is black in color and present pyramid morphology; E) Purple minerals with tabular habit are associated with coquimbite.

the sub-group with the formula $\mathrm{A} \mathrm{XO}_{4} \cdot \mathrm{x}\left(\mathrm{H}_{2} \mathrm{O}\right)$. Finally, voltaite displays black pyramidal shaped crystals under the SEM (Fig. 8D) and is the only member of Hydrated Acid and Sulfates with miscellaneous formula. Generally, it is present in the cave as crusts and crystals on the walls, floor, and roof. The presence of voltaite has been confirmed by XRD and microRaman techniques.

\section{Hydrated sulfates containing hydroxyl or halogen}

This group comprises minerals of the copiapite group, represented in CMI by aluminocopiapite, copiapite, ferricopiapite, and magnesiocopiapite. These minerals are common forming part of geysermites and normally show yellow colors, and sometimes a tabular habit (Fig. 10B). Ferricopiapite and magnesiocopiapite are new cave minerals confirmed by XRD.

Other minerals (native elements, halides, oxides, and silicates)

Native sulfur was detected in 11 samples from CMI by FT-Raman, micro-Raman, and XRD. Native sulfur deposits in this cave appear close to volcanic vents as crusts made of crystals $<5 \mathrm{~cm}$ large, in high temperature areas, acid conditions ( $\mathrm{pH} \sim 2)$ and sometimes forming stalactites in association with anhydrite (Fig. 7).

The possible presence of the halide tolbachite is suggested by XRD as accessory mineral associated with römerite, gypsum, melanterite, rozenite, and szomolnokite, detected in the same stalactite. This mineral was forming part of a light green stalactite
(>8 cm length) in CMI. Tolbachite was not reported from cave environments yet.

The only oxide detected, goethite, was found in CMU as dark orange and reddish masses filling cracks in the walls. It was identified by XRD in only one sample. The only phyllosilicate identified is kaolinite, found in a single muddy yellow sample from CMU. It was associated with natrojarosite and minor gypsum in snottite-like speleothems hanging from the roof of the cave, probably related to extremophile microorganism activity (pH 1-2). Finally, marinellite was identified by micro-Raman spectrometry in two different samples, but it was not confirmed or detected by XRD.

\section{Mineral distribution and speleothems}

Mineral distribution in CMI is represented in Fig. 5, however due to the high diversity and possible spatiotemporal variable distribution of minerals (e.g., different temperature and relative humidity affecting the hydration state of some hydrous minerals), this study did not aimed at quantitatively estimating this spatial diversity. Other techniques, including photogrammetry or LIDAR scanning may be necessary.

Most of the reported sulfate minerals are very soluble, therefore, the only reason why they exist in the tropical weather of Costa Rica (rainy season from May to November, with 2,387 mm/yr) is because of the particular cave climate conditions. Most minerals in CMI occur as crusts on the wall and roof and are concentrated on the northern side and also covering walls and roof of the Sala de los Cristales Verdes (where most of the stalactites are located). Other speleothems such as stalactites and stalagmites are associated with $\mathrm{SO}_{4}{ }^{2-}$ and $\mathrm{Fe}-$ rich infiltration waters (Fig. 11 and 4B), or Ca-rich solutions as a particular anhydrite-sulfur stalactite (Fig. 7). Geysermites are associated with $\mathrm{SO}_{4}{ }^{2-}$ rising thermal waters, and present high-mineral diversity with more than 11 mineral species in a single sample. Most of the identified mineral species present yellow, white, and translucent color followed by green. The most common mineral habits are acicular followed by massive. Most of the crust minerals are centimeters in size, while stalactites and geysermites are normally decimeters.

\section{Elemental analyses and microphotography}

The results of 93 EDX analyses on samples from both caves allowed the detection of 17 chemical ions and their relative abundance (Supplementary Table 5). Presence of iron is related with abundant iron sulfate mineral phases (e.g., coquimbite, copiapite, ferricopiapite, rozenite). Other metals such as aluminum have been detected in several samples associated with sulfates containing Al (e.g., marinellite, alunogen, dietrichite, halotrichite, 


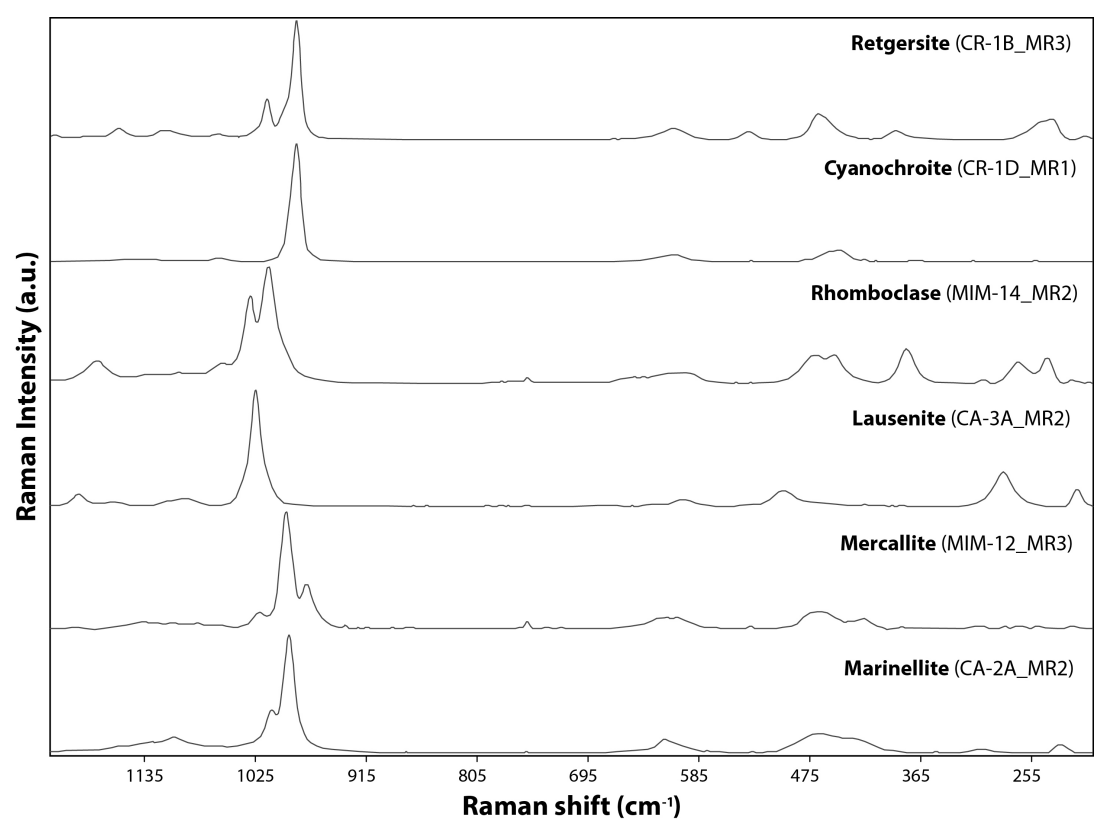

Fig. 9. Micro-Raman spectra of the new cave minerals reported only by this technique. along active faults in the Irazú caves area may have caused the formation of the underground voids.

This pseudokarstic mechanism is evidenced by the presence of a cylindrical hole $\sim 1 \mathrm{~m}$ in diameter in the roof of the cave, similar to holes formed in dissolution caves. Linked to this, in Llano Grande mine quarry $(6.5 \mathrm{~km} \mathrm{SW}$ of the Crater Activo), there are channels $\sim 1$ to $2 \mathrm{~m}$ wide in similar pyroclastic hydrothermally altered rocks, completely filled with native sulfur. Likewise, these presumed proto-channels were found during a drilling campaign, when a borehole intersected a possible hypogenic cave, $\sim 1$ to $\sim 5 \mathrm{~m}$ depth. Therefore, a combination of tectonic, weathering, high temperature degasification, leaching, and erosion could be involved in the genesis of the caves on Irazú Volcano. pickeringite, aluminocopiapite). The presence of $\mathrm{Si}$ can be associated with the silicates (e.g., kaolinite or marinellite) and diatom skeletons found in the sample MU-170514-4 next to snottites (at $\mathrm{pH} \sim 2$ ). Alkaline elements, such as calcium correspond to gypsum but can also be related to other minerals such as marinellite, anhydrite, and copiapite. The other alkaline cations detected by $\operatorname{EDX}(\mathrm{Na}, \mathrm{Mg}, \mathrm{K})$ are quite common in many samples. $\mathrm{V}, \mathrm{Br}$, and $\mathrm{Sr}$ were also reported but no mineral containing those elements has been identified in this work. This suggests that there could be more minerals present in the samples. SEM photographs of the samples show complex associations between these minerals and are useful to distinguish the different habits (Fig. 7, 8, 10, and 11).

\section{DISCUSSION}

\section{Speleogenesis}

The caves of the Irazú Volcano have a complex origin, which differs considerably from the speleogenetic mechanisms associated with normal carbonic and sulfuric acid caves worldwide (Hose et al., 2000b; Klimchouk, 2009; Onac et al., 2009). Ulloa et al. (2013) analyzed different possible mechanisms for the origin of CMI (i.e., landslide, phreatic explosion, or water runoff). These authors concluded that the landslide model with a stepped fault plane generated these caves. However, preliminary results of Baldoni et al. (pers. comm.) estimated a rock removal rate of $\sim 3,000 \mathrm{~m}^{3} / \mathrm{yr}$ in the Irazú-Turrialba system by chemical leaching from the springs. Also, based on an infrared survey in 1964, thermal anomalies were also identified (Gawarecki et al., 1980), which coincide with the Rio Sucio fault traces and some of them were located close ( $250 \mathrm{~m} \mathrm{NW})$ to the actual position of the caves (covered by the material that slipped in 1994). Therefore, the possibility exists that dissolution weathering and underground removal of volcanic pyroclastic rocks by very acid waters

\section{Sulfur in the caves}

Sulfur is common in sulfuric acid caves [e.g., Cueva Villa de la Luz (Mexico; Hose et al., 2000); Carlsbad and Lechuguilla caves (New Mexico; Hill, 1995); Lower Kane Cave ( Wyoming; Egemeier, 1981); Diana Cave (Romania; Onac et al., 2009); Santa Cesarea Terme (Italy; D’Angeli et al., 2017)] as wall crusts and stalactites, in places associated with gypsum (Hill \& Forti, 1997). On Irazú Volcano, elemental sulfur has been reported in fumaroles (Stoiber $\&$ Rose, 1974) and as sulfur flow in the main crater in 1982 (McClelland et al., 1989). In the Irazú caves, elemental sulfur is present in some volcanic vents on the eastern wall of the cave (pH 1-2) and crystals can be up to $6 \mathrm{~cm}$ in length. Furthermore, elemental sulfur was found in a $\sim 10 \mathrm{~cm}$

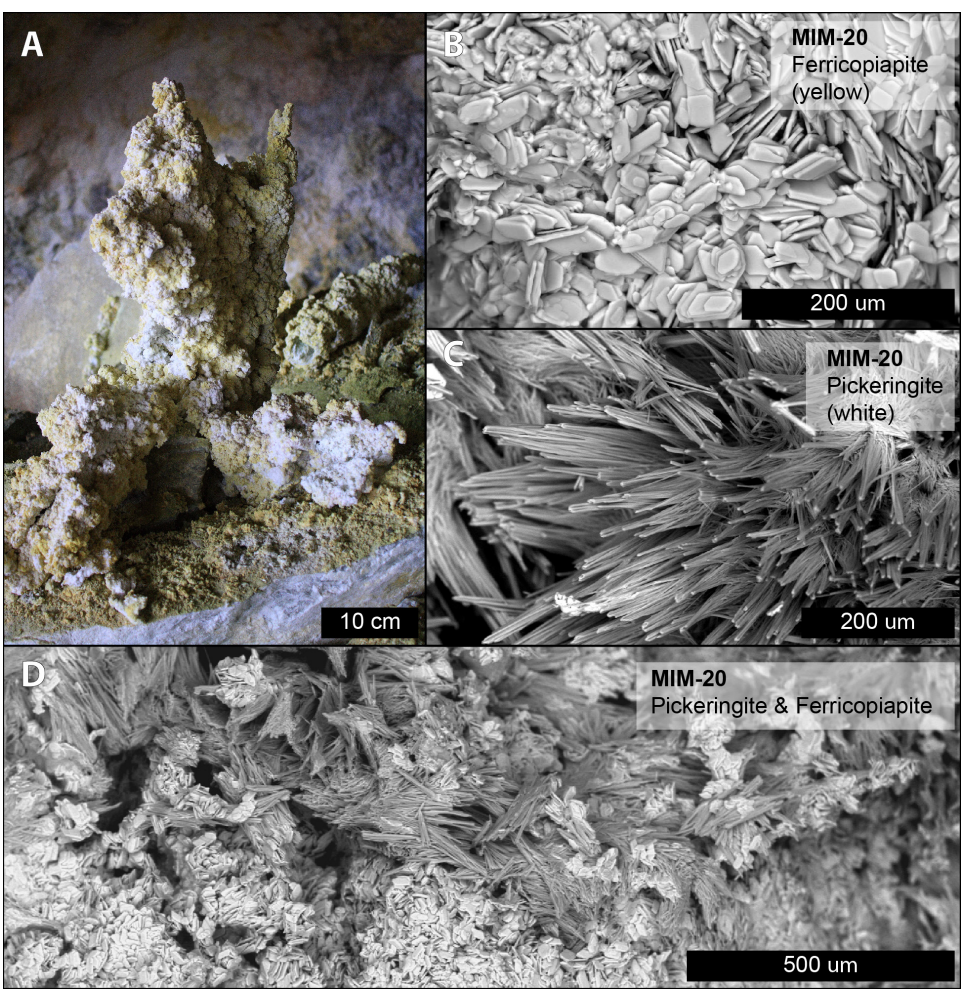

Fig. 10. An example of geysermite (Photography taken by Victor Carvajal in 2011) in CMI (A); SEM microphotograph correspond to ferricopiapite (B and D); and pickeringite minerals ( $C$ and $D)$. 
long stalactite (Fig. 7A). Similar sulfur speleothems have been reported in strongly acid environments as a result of H2S oxidation (Forti \& Mocchiutti, 2004; D'Angeli et al., 2017). Sulfur is present in all the EDX analyses (Supplementary Table 5), ranging from 5.2 to $70.8 \mathrm{wt} \%$. The abundant presence of sulfur in these minerals, is related to the typically sulfur-rich volcanic environments. Sulfur is present in a variety of valence states; the most reduced form as hydrogen sulfide $\left(\mathrm{H}_{2} \mathrm{~S}\right)$ in volcanic gases is -2 , elemental sulfur (valence $0)$ and the most oxidized form as sulfate $\left(\mathrm{SO}_{4}{ }^{2-}\right)$ is +6 . Some of the changes in valence are attributed to the biogeochemical reactions, in which microorganisms frequently play a main role as catalysts, taking advantage of the associated electron fluxes to satisfy their metabolic needs (Morse et al., 1987).

\section{Minerogenetic mechanisms in the Irazú caves}

The transport of ions and chemical compounds in the caves and the consequent mineral precipitation can occur from mineralized solutions and this may happen both in subaerial or subaqueous settings. Each of the transport mechanisms can trigger different minerogenetic processes. Mineralized solutions plays a very important role in the transportation of chemical elements and compounds into the caves. Water geochemistry analyses indicate considerable concentrations of sulfates in the main crater lake (Supplementary Table 1), and infiltration water analyses indicated the presence of $\mathrm{Se}, \mathrm{Fe}, \mathrm{Al}$, $\mathrm{Ca}, \mathrm{Mg}, \mathrm{Na}, \mathrm{Mn}, \mathrm{K}, \mathrm{Zn}, \mathrm{Ni}$, and $\mathrm{Co}$ ions (Fig. 3C). Selenium is the only element that is not reflected in the elemental composition of the reported minerals. Enrichment in selenium (993.1 mg/1) might be associated with the input of geothermal waters (Floor \& Román-Ross, 2012). Iron concentration is 440.2 ppm in the infiltration waters and is present in the chemical composition of 20 minerals, followed by calcium present in 14 different minerals. Stalactites and stalagmites (usually green to blue in color) are associated with dissolution-precipitation processes of Fe-sulfate-rich infiltration waters. They are found in "Sala de los Cristales Verdes", formed by iron hydrated

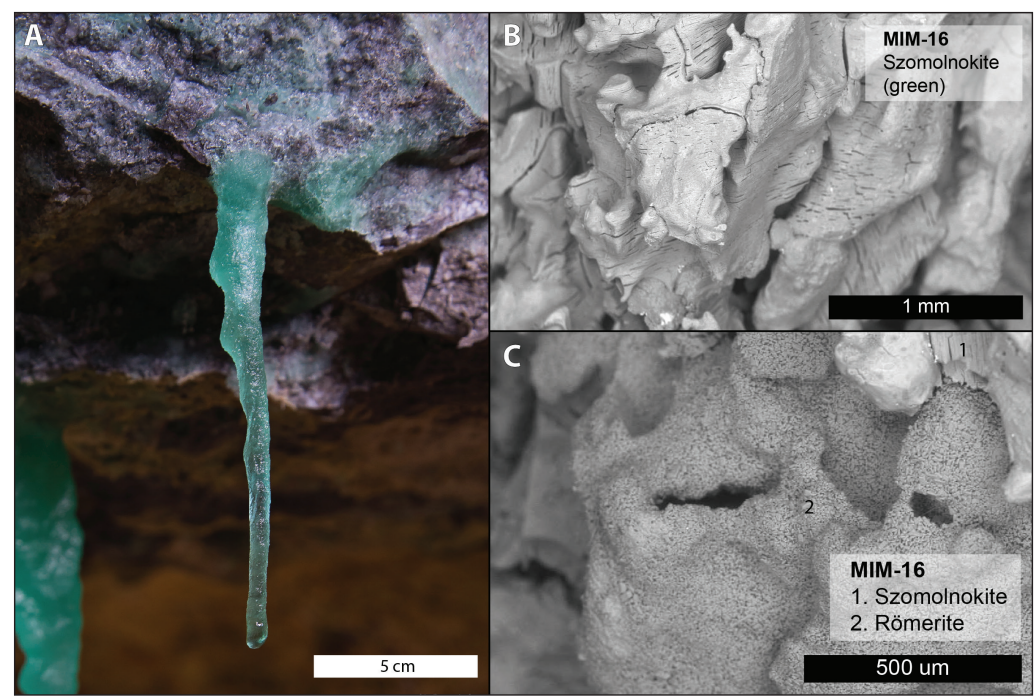

Fig. 11. Example of szomolnokite stalagmite $\sim 15 \mathrm{~cm}$ long (Photography taken by Victor Carvajal in 2014) in CMI (A); SEM image of similar szomolnokite samples (B and $C)$, in association with römerite $(C)$. sulfates including melanterite, szomolnokite, römerite, rozenite, and voltaite with presence of gypsum (probably in lower quantities) and possible tolbachite. In the case of iron sulfate minerals as szomolnokiterozenite-melanterite-römerite, they differ from each other by their content in water molecules, with hydration and dehydration processes possibly causing their transformation from one species to another. The growth of the blue-green stalactite (Fig. 4B) is relatively fast: based on field observations (growth and collapse of green-stalactites) they can grow in the order of $\sim 30 \mathrm{~cm} / \mathrm{a}$. Similar melanterite stalactites and stalagmites have been reported in caves in California, Nevada, and Tennessee (USA), Sicily (Italy), and mine caves (Hill \& Forti, 1997).

At least 7 different geysermites have been identified in CMI distributed in the main chamber and ranging from $\sim 15$ to $\sim 40 \mathrm{~cm}$ height and $\sim 8$ to $\sim 15 \mathrm{~cm}$ width (Fig. 5 and 10). Field observations revealed no thermal anomalies in these speleothems suggesting that the process that formed them, is not currently active. The mineralogical composition of the analyzed geysermites consists of hydrated acid sulfates (apjohnite, coquimbite, dietrichite, halotrichite, kalinite, pickeringite, and wupatkiite) and hydrated sulfates containing hydroxyl or halogen (aluminocopiapite, copiapite, ferricopiapite, magnesiocopiapite). The genesis of these geysermites is related to upwelling sulfate-rich waters of the Irazú hydrothermal system. The cooling of the rising thermo-mineral fluids induced supersaturation and mineral precipitation (Onac \& Forti, 2011b) and may explain the high mineralogical diversity of such speleothems. The presence of geysermites suggests the existence of lower thermal aquifers which can be responsible of acid drainage in the Río Sucio River basin (Arce-Rodríguez et al., 2017) and some thermal springs in the surroundings.

Aerosols (solid or colloidal particles, $10^{-7}$ to $10^{-2}$ $\mathrm{cm}$ ) and hydroaerosols (liquid droplets) are another way to transport chemical compounds, which is a feasible mechanism where there is a mixture of air at different temperatures in caves (Cigna \& Hill, 1997). Speleothems associated with aerosols are related to thermal caves (preferable associated with fumarole vapors), where temperature and humidity gradients are present (Onac \& Forti, 2011b). Speleothems associated with aerosols as transport-media of chemical compounds is strongly suggested for CMI because: (1) presence of minerals close to hydrothermal vents, higher density and radial distributions around them; (2) elevated concentrations of $\mathrm{SO}_{4}{ }^{2-}$ in fumarolic analyses (Table 1) and presence of $\mathrm{H}_{2} \mathrm{~S}$ in the cave atmosphere (29 ppm) being evidence of sulfur-compounds in the air; (3) some minerals present morphologies similar to "rims and blisters" (according to the description of Onac \& Forti, 2011b), which are associated with speleothems developed by aerosols and vapors. CMU did not present considerable thermal anomalies and shows less mineral diversity, which could be suggesting that aerosols are probably one of the most 
active mechanisms in the higher mineral diversity of CMI.

The presence of elemental sulfur crystals in CMI could be associated with cooling down of fumarole gases (sublimation at temperatures $>100^{\circ} \mathrm{C}$ ), which is suggested as minerogenetic mechanism (Forti, 2005; Onac \& Forti, 2011b). The atmosphere of CMI is rather complex, and shows significant variations in temperature $\left(9\right.$ to $\left.30^{\circ} \mathrm{C}\right)$ and relative humidity $(74.2$ to $92.4 \%)$. These variations can influence precipitation of aerosol minerals and also rule the hydratationdehydratation processes for those mineral species that only differ in their water content (e.g., aplowitebieberite, epsomite-hexahydrite and melanteriterozenite-szomonolkite series).

Finally, another possible mineral-forming mechanism in the cave is microbial activity. This mechanism is suggested based on field observations where gypsumstalactite are intrinsically related to snottites in some parts of the cave.

\section{Relative abundance of elements and minerals}

CMI may be the cave (or one of the caves) in the world with the greatest mineralogical diversity. Because of the particular conditions in an active volcano environment $\left(\mathrm{SO}_{4}{ }^{2-}\right.$ rich waters and influence of volcanic gases), 48 minerals species have been identified, 41 are confirmed and 7 mineral species are suggested. According to Onac \& Forti (2011a) in the past 20 years, on average, three new cave minerals per year have been discovered. This study adds 18 minerals to the list Onac \& Forti (2011a), including 12 confirmed sulfates (aplowite, bieberite, boyleite, dietrichite, ferrinatrite, ferricopiapite, lausenite, lishizhenite, pentahydrite, magnesiocopiapite, szomolnokite, and wupatkiite), one confirmed silicate (marinellite), four other possible sulfates (cyanochroite, mercallite, retgersite, and rhomboclase, Fig. 9), and also the possible presence of an halide (tolbachite). Five of these new cave minerals (aplowite, ferrinatrite, magnesiocopiapite, wupatkiite, and boyleite) in CMI were previously reported by Ulloa et al. (2013) and apjohnite is not in the cave minerals list of Onac \& Forti (2011a), but was reported by Onac et al. (2009). However, it must be considered that the number of minerals present in these caves is still underestimated because it was not possible to associate some of the Raman spectra with any specific mineral species of the Raman database, as well as the presence of more elements (e.g., Br, Sr, V) identified by EDX analyses (Supplementary Table 5) which are not reflected in the composition of the minerals listed in Table 2.

Apart from selenium, the majority of elements in infiltration waters (Fig. 3C) corresponds to the most abundant elements present in the identified sulfates (Fig. 6D). Fe, Al, $\mathrm{Ca}, \mathrm{Na}$, and $\mathrm{Mg}$ are the most abundant cation species in sulfates and also the major elements in infiltration waters. Thus, the abundance of accessory elements in sulfate minerals is proportional to the abundance of elements in the infiltration waters.

Gypsum is probably the most abundant mineral in the cave. The north walls of CMI are totally covered with gypsum crystals, mainly along the external edge of the cave, and this mineral is also present in CMU. Gypsum tends to be idiomorphic and some of the crystals presents an interesting association with microbial mats.

\section{Summit volcanic crater lake and hydrothermal system}

The last eruptive activity of the main Irazú crater stopped after 1965 and in July of the same year the volcanic lake was formed in the main crater. The last eruptive activity of the main Irazú crater stopped after 1965 and in July of the same year the volcanic lake was formed in the main crater. This lake has an ephemeral behavior, being repeatedly dry (years 1977, 1979, 1982-83, 1987, 1990, and 2013-17) and precipitation has not been the main factor in its change in volume. Fumaroles and sub-aquatic fumaroles have also been reported at different timeintervals, during 1973, 1977-1978, 1982, 19851986, 1991-2000, and 2002-2008 (Ramirez et al., 2013 and references therein). The lake of the main crater showed important changes in $\mathrm{pH}$, temperature, chemical composition (Fig. 3A and B; Supplementary Table 1) and water level since 1991, making this lake a complex geochemical system. An acidification trend in the lake was measured in the years 1991-1993 and was associated with enrichment in $\mathrm{SO}_{4}{ }^{2-}$ and $\mathrm{Cl}^{-}$. After 2000, lower concentrations of $\mathrm{SO}_{4}{ }^{2-}$ and $\mathrm{Cl}^{-}$were detected and an alkaline trend predominated. The average temperature of the lake is $29.5^{\circ} \mathrm{C}$, although it showed temperatures over $50^{\circ} \mathrm{C}$ in 1991 and 2003.

These variations in water levels and volcanic gas emissions are strongly associated with the active faulting and secondary permeability in the volcanic conduit. Based on historical reports it is suggested that rising of hot fluids and volcanic gases from the hydrothermal system has changed over time, sometimes reaching the volcanic crater-lake level. Hydraulic communication between the main crater lake, and the caves and hydrothermal system is suggested. The main supporting signs are: the presence of diatom skeletons in a sample in a dripping zone at CMU, which may come from lake; the enrichment in sulfates in historical water analyses of the main crater lake associated with infiltration waters in the caves and presence of sulfate minerals in the cave. The hydraulic connection lake-caves coinciding with the model proposed by Ramírez et al. (2013) is associated with high-permeability pathways within the faults. According to this hypothesis, variations of regional tectonic forces, seismic activity, clays on cracks, and raining may be factors controlling the ephemeral behavior of Irazú Volcanic Lake in the Crater Principal.

For periods for which water geochemical analyses are available (Supplementary Table 1) in Irazú Volcanic Lake, evidence of sub-aquatic fumarole activity is reported for years 1991, 1992, and 2003 to 2008 (Ramirez et al., 2013). These ephemeral volcanic emissions are connected with different pulses of the hydrothermal system activation and probably directly linked with variations in the geochemical lake system. According to this model, cave inputs of sulfate-rich 
waters can present two origins, one related with volcanic lake infiltration, which was presently active during field trips. A second sulfate-rich water source is suggested, related with the rising of geothermal fluids through faults, which can provide permeable paths. Infiltration sulfate-rich solutions are responsible for speleothem precipitation, such as stalactites and stalagmites, whereas geothermal rising sulfate-rich waters probably caused the formation of geysermites.

\section{Fumaroles and diffuse gas at Irazú System}

Sulfur and gypsum minerals have been reported as fumarole minerals in the volcano (Stoiber \& Rose, 1974). Fumarole locations have changed over the last decades, but actually at least two still active fumaroles are present in the northwest part of Irazú Volcano (Fig. 1A). In the area affected by the 1994 landslide another fumarole was present, maybe associated with the actual location of the caves. The only published data from Irazú fumaroles shows concentrations of $\mathrm{CO}_{2}$ from $98.0 \%$ to $99.8 \%, \mathrm{SO}_{2}$ from $0.106 \%$ to 0.007 $\%$ and $\mathrm{H}_{2} \mathrm{~S}$ from $0.015 \%$ to $0 \%$ in 1981 and 1982, respectively (Global Volcanism Program, 1983) and $\mathrm{CO}_{2}$ 98.9\% and $\mathrm{H}_{2} \mathrm{~S} \quad 0.8 \%$ in the year 1993 (Global Volcanism Program, 1993). The compiled historical analyses of Irazú fumaroles (Table 1) shows an important content of $\mathrm{SO}_{4}{ }^{2-}$ ranging from 42 to $503 \mathrm{mg} / 1$, being $\mathrm{SO}_{4}{ }^{2-}$ the most abundant compound, making aerosols mineralogenesis a potential mechanism.

Irazú Volcano also presents an important diffuse $\mathrm{CO}_{2}$ flux: Galindo et al. (2004) established a $\mathrm{CO}_{2}$ base flux at $\sim 20 \mathrm{gm}^{-2} \mathrm{~d}^{-1}$ and maximum values of $316 \mathrm{~g}$ $\mathrm{m}^{-2} \mathrm{~d}^{-1}$ for sites studied in 2001, while Epiard et al. (2017) reported maximum values of $2.71 \times 10^{4} \mathrm{gm}^{-2} \mathrm{~d}^{-1}$ for the northern flank and $2.17 \times 10^{3} \mathrm{gm}^{-2} \mathrm{~d}^{-1}$ north of the main crater in 2015. Those diffuse $\mathrm{CO}_{2}$ flux anomalies are located in areas close to active fault traces, being the structural control very important for the escape of gases and associated rock alteration, but probably with less relevance for the formation of speleothems in the caves of the Irazú Volcano.

\section{Implications for planetary exploration}

Caves are considered extreme environments for life because they are resource-limited due to the absence of light and implicitly of photosynthesis; however, chemolithoautotrophic organisms can metabolize inorganic elements such as iron, sulfur, and manganese in caves (Northup et al., 2011, 2012; Riquelme \& Northup, 2013). Thus, terrestrial subterranean environments and secondary cave minerals (speleothems) have drawn attention as potential analogues of life niches for planetary exploration, especially Mars (Boston et al., 2001; Bost et al., 2013; Gázquez et al., 2014). During the past decades important efforts have been done by the scientific community to understand primary composition of Mars and alteration products that are associated with paleo-environmental conditions of the planet. Chemical analyses suggest than the Martian crust is basaltic, where mineralogy is dominated by primary silicates (e.g., olivine, clinopyroxene, orthopyroxene, plagioclase, alkali feldspars) and secondary minerals groups (e.g., oxides, clay minerals, hydrated silicates, carbonates, sulfates, and chlorides). These secondary minerals are associated with alteration related to presence of liquid water in some stage of the Martian evolution ( Mustard et al., 2008; Ehlmann \& Edwards, 2014;). The discovery on the Martian surface of soil sulfur-enrichment (Chevrier \& Mathé, 2007), presence of jarosite suggestive of existence of acidic waters $(\mathrm{pH}<4)$ (Ehlmann \& Edwards, 2014; Thollot et al., 2012), Ca, Fe, and Mg-sulfates (Ehlmann \& Edwards, 2014) and $\mathrm{CO}_{2}$-rich atmosphere, are factors which coincide with the mineralogy and some physical data presented in this article for the Irazú volcanic caves. Therefore, we consider that our investigated caves can be used as analogue for the Mars environment. Future geomicrobiological analyses on these caves could give us clues in understanding the potential life-forms and geo-environmental interactions from an astrobiological perspective.

\section{CONCLUSIONS}

The northwest flank of the Irazú Volcano accommodates three volcanic caves, of which CMI and CMU have been studied in detail. The speleogenetic process that generated these caves is complex and involved tectonic (fault zone), weathering, high temperature degasification, leaching and erosion. The caves are developed in interbedded pyroclastic rocks, affected by hydrothermal alteration.

The studied caves show an extremely high mineralogical diversity, with forty-eight identified mineral species. The secondary mineral assembles of the studied caves are constituted mainly by sulfates, most of them belonging to hydrated acid and sulfates sub-group. Other mineral groups are also present, including native elements and minor halides, oxides and silicates. Thirteen of the mineral species are confirmed as new cave minerals, whereas five others are not confirmed yet by various techniques.

The particular environmental conditions in the studied caves, including location in an active volcano, active faulting, presence of thermal anomalies, interaction of sulfate-rich and acid water from volcanic lake infiltration, and probably rising of geothermal waters somewhere in the history of the caves, are the main factors that control this extreme mineralogical diversity.

\section{ACKNOWLEDGEMENTS}

This project was supported by Centro de Investigación en Ciencias Geológicas of Universidad de Costa Rica (830-B7-A00) and the Costa Rican Department of Science and Technology (MICITT) fund FI-160B-14 to Andrés Ulloa Carmiol. We acknowledge the Administration of the Parque Nacional Volcán Irazú, ACCVC for the research and access permits. Esmeralda Urea is thanked for the SEM-EDX analyses. Field assistance for cave survey, photography and sample collection were supported by members of Grupo Espeleológico Anthros (S. Trescott, M. Vargas, V. Carvajal, R. Ramírez, D. Brizueña, J.G. Badilla, C. 
Soto, S. Brenes, A. Alvarado, F. Alvarado I. Baldizón, D. Salazar), and also H. Madrigal, D. Rocchi, A. Haydock, K. Hicks, F. Calvo, and W. Hernández. The company AERODIVA S.A. is thanked for facilitating the aerial photographs for Fig. 1A and 2A and the digital elevation model of the Irazu Volcano, through the Comisión Nacional de Prevención de Riesgos y Atención de Emergencias. Cusuko Fotografia is tanked by the aerial photograph of Fig. 2B. We thank Esteban Gazel for collaborated in the infiltration water analyses and Gerardo Soto is thanked for clarifying information about old chemical analyses. We would also like to show our gratitude to Professors Bogdan P. Onac, Paolo Forti, and Carol A. Hill, for helpful suggestions.

\section{REFERENCES}

Alvarado G.E., 1993 - Volcanology and petrology of Irazú Volcano, Costa Rica. Unpublished PhD, Kiel University, $261 \mathrm{p}$.

Alvarado G.E., Carr M.J., Turrin B.D., Swisher C.C., Schmincke H.-U. \& Hudnut K.W., 2006 - Recent volcanic history of Irazú volcano, Costa Rica: Alternation and mixing of two magma batches, and pervasive mixing. Geological Society of America Special Papers, 412: 259-276. https://doi.org/10.1130/2006.2412(14)

Alvarado G.E., Mora M.M. \& Ulloa A., 2013 - La caída de "ceniza" proveniente3 del volcán Irazú (Costa Rica) el 8 de diciembre de 1994: ¿Una explosión freática? Revista Geológica de America Central, 48: 159-168.

Arce-Rodríguez A., Puente-Sánchez F., Avendaño R., Libby E., Rojas L., Cambronero J.C., Pieper D.H., Timmis K.N. \& Chavarria M., 2017 - Pristine but metalrich Rio Sucio (Dirty River) is dominated by Gallionella and other iron-sulfur oxidizing microbes. Extremophiles, 21: 235-243. https://doi.org/10.1007/s00792-016-0898-7

Bost N., Westall F., Ramboz C., Foucher F., Pullan D., Meunier A., Petit S., Fleischer I., Klingelhöfer G. \& Vago J.L., 2013 - Missions to Mars: Characterisation of Mars analogue rocks for the International Space Analogue Rockstore (ISAR). Planetary and Space Science, 82-83: 113-127. https://doi.org/10.1016/j.pss.2013.04.006

Boston P.J., Spilde M.N., Northrup D.E., Melim L.A., Soroka D.S., Kleina L.G., Lavoie K.H., Hose L.D., Mallory L.M., Dahm C.N., Crossey L.J. \& Schelble R.T., 2001 - Cave Biosignature Suites: Microbes, Minerals, and Mars. Astrobiology 1: 25-55.

https://doi.org/10.1089/153110701750137413

Chevrier V. \& Mathé P.E., 2007 - Mineralogy and evolution of the surface of Mars: A review. Planetary and Space Science, 55: 289-314.

https://doi.org/10.1016/j.pss.2006.05.039

Cigna A.A. \& Hill C.A., 1997 - Aerosols: Are they a mechanism of speleothem growth? In: Hill C.A. \& Forti P. (Eds.), Cave minerals of the world. National Speleological Society, Alabama, p. 255-258.

Daza R. \& Bustillo M.Á., 2014 - Exceptional silica speleothems in a volcanic cave: A unique example of silicification and sub-aquatic opaline stromatolite formation (Terceira, Azores). Sedimentology, 61: 21132135. https://doi.org/10.1111/sed.12130

D’Angeli I.M., Vattano M., Parise M., De Waele J., 2017 The coastal sulfuric acid cave system of Santa Cesarea Terme (Southern Italy). In: Klimchouk A., Palmer A.N., De Waele J., Auler A.S. \& Audra P. (Eds.), Hypogene karst regions and caves of the world. Springer, p. 161168. https://doi.org/10.1007/978-3-319-53348-3 9
DeMets C., 2001 - A new estimate for present-day CocosCaribbean plate motion:Implications for slip along the Central American volcanic arc. Geophysical Research Letters, 28: 4043-4046.

https://doi.org/10.1029/2001GL013518

Eaton A.D., Clesceri L.S., Greenberg A.E. \& Franson M.A.H., 1998 - Standard methods for the examination of water and wastewater. American Public Health Association, Washington DC.

Ehlmann B.L. \& Edwards C.S., 2014 - Mineralogy of the Martian surface. Annual Review of Earth and Planetary Sciences, 42: 291-315.

https://doi.org/10.1146/annurev-earth-060313-055024

Epiard M., Avard G., de Moor J.M., Martínez Cruz M., Barrantes Castillo G. \& Bakkar H., 2017 -Relationship between diffuse $\mathrm{CO}_{2}$ degassing and volcanic activity. Case study of the Poás, Irazú, and Turrialba Volcanoes, Costa Rica. Frontiers in Earth Science, 5: 1-14. https://doi.org/10.3389/feart.2017.00071

Floor G.H. \& Román-Ross G., 2012 - Selenium in volcanic environments: A review. Applied Geochemistry, 27: 517531. https://doi.org/10.1016/j.apgeochem.2011.11.010

Forti P., 2005 - Genetic processes of cave minerals in volcanic environments: An overview. Journal of Cave and Karst Studies, 67 (1): 3-13.

http://ww.caves.org/pub/journal/PDF/V67/v67n1Forti.pdf

Forti P., 1994 - Cave minerals in volcanic caves. Proceedings of the $\mathrm{I}^{\circ}$ Incontro Internacional de Vulcanoespeleologia Das Ilhas Atlanticas, Pico, Acores, p. 1-98.

Forti P., Galli E. \& Rossi A., 200 - Minerogenesis of volcanic caves of Kenya. International Journal of Speleology, 32: 3-18.

https://doi.org/10.5038/1827-806X.32.1.1

Forti P., Galli E., Rossi A., Pint J. \& Pint S., 2004 - Ghar Al Hibashi lava tube: the richest site in Saudi Arabia for cave minerals. Acta Carsologica, 33: 189-206.

Forti P. \& Mocchiutti A., 2004 - Le condizioni ambientali che permettono l'evoluzione di speleotemi di zolfo in cavità ipogeniche: nuovi dati dalle grotte di Capo Palinuro (Salerno, Italia). Grotte d'Italia, 4: 39-48.

Galindo I., Melián G. V, Salazar J.M.L. Hernández P.A., Pérez N.M., Ramírez C., Fernández M., Alvarado G.E., Sumino H. \& Notsu K., 2004 - Emisión difusa de dióxido de carbono en el volcán Irazú, Costa Rica. Revista Geológica de America Central, 30: 157-165. https://doi.org/10.15517/rgac.v0i30.7284

Gawarecki S., Moxhan R., Morgan J. \& Parker D., 1980 - An infrared survey of Irazú volcano and vicinity, Costa Rica. In: Fourteenth International Symposium on Remote Sensing of Environment, San José, Costa Rica 1901-1912.

Gàzquez F., Rull F., Calaforra J. M., Venegas G., Manrique J. A., Sanz A., Medina J., Català-Espi A., Sansano A., Navarro R., Forti P., De Waele J. \& Martinez-Frìas J, 2014 - Caracterización mineralógica y geoquímica de minerales hidratados de ambientes subterráneos: implicaciones para la exploración planetaria. Estudios Geológicos, 70 (2): e009. https://doi.org/10.3989/egeol.41688.314

Giggenbach W.F., 1975 - A simple method for the collection and analysis of volcanic gas samples. Bulletin Volcanologique, 39: 132-145. https://doi.org/10.1007/BF02596953

Global Volcanism Program, 1983 - Report on Irazu (Costa Rica). In: McClelland L. (Ed.), Scientific event alert network bulletin. Smithsonian Institution, 8:10.

Global Volcanism Program, 1993 - Report on Irazu (Costa Rica). In: Venzke E. (Ed.), Bulletin of the global volcanism network. Smithsonian Institution, 18: 9. 
Hill C.A. \& Forti P., 1997 - Cave minerals of the world. National Speleological Sociaty, Huntsville, Alabama, $463 \mathrm{p}$.

Hose L.D., Palmer A.N., Palmer M.V, Northup D.E., Boston P.J. \& Duchene, H.R., 2000 - Microbiology and geochemistry in a hydrogen-sulphide-rich karst environment. Chemical Geology, 169: 399-423.

https://doi.org/10.1016/S0009-2541(00)00217-5

Hose L.D. \& Pisarowicz J.A., 1999 - Cueva de Villa Luz, Tabasco, Mexico: Reconnaissance study of an active sulfur spring cave and ecosystem. Journal of Cave and Karst Studies, 61: 13-21.

http://ww.caves.org/pub/journal/PDF/V61/v61n1Hose.pdf

Jones D.S., Schaperdoth I. \& Macalady J.L., 2016 Biogeography of sulfur-oxidizing Acidithiobacillus populations in extremely acidic cave biofilms. The ISME Journal 1-13. https://doi.org/10.1038/ismej.2016.74

Klimchouk A., 200 - Morphogenesis of hypogenic caves. Geomorphology, 106: 100-117. https://doi.org/10.1016/j.geomorph.2008.09.013

Laetsch T. \& Downs R., 2006 - Software for identification and refinement of cell parameters from powder diffraction data of minerals using the RRUFF project and American Mineralogist Crystal Structure Databases. In: $19^{\text {th }}$ General Meeting of the International Mineralogical Association, Kobe, Japan, p. 8-25.

Lalla E.A., Lopez-Reyes G., Sansano A., Sanz-Arranz A., Martínez-Frías J., Medina J. \& Rull-Pérez F., 2016 - Raman-IR vibrational and XRD characterization of ancient and modern mineralogy from volcanic eruption in Tenerife Island: Implication for Mars. Geoscience Frontiers, 7: 673-681. https://doi.org/10.1016/j.gsf.2015.07.009

Lalla E.A., López-Reyes G., Sansano A., Sanz-Arranz A., Schmanke D., Klingelhöfer G., Medina-García J., Martínez-Frías J. \& Rull-Pérez F., 2015 - Estudio espectroscópico y DRX de afloramientos terrestres volcánicos en la isla de Tenerife como posibles análogos de la geología marciana. Estudios Geológicos, 71: 1-19. https://doi.org/10.3989/egeol.41927.354

Marshall J.S., Fisher D.M. \& Gardner T.W., 2000 - Central Costa Rica deformed belt: Kinematics of diffuse faulting across the western Panama block. Tectonics 19: 468492. https://doi.org/10.1029/1999TC001136

McClelland L., Sinkin T., Summers M., Nielsen E. \& Stein T.C., 1989 - Global volcanism. Prentice Hall, Inc., New Yersey, 465 p.

Miller A.Z., Pereira M.F.C., Calaforra J.M., Forti P., Dionísio A. \& Saiz-Jimenez C., 2014 - Siliceous Speleothems and Associated Microbe-Mineral Interactions from Ana Heva Lava Tube in Easter Island (Chile). Geomicrobiology Journal, 31: 236-245. https://doi.org/10.1080/01490451.2013.827762

Mindat - https://www.mindat.org/ [accessed 1.2.18].

Montero W., 2001 - Neotectónica de la región central de Costa Rica: frontera oeste de la microplaca Panamá. Revista Geológica de América Central, 24: 29-56.

Montero W. \& Alvarado G., 1995 - El terremoto de Patillos del 30 de diciembre de $1952(M s=5$,9) y el contexto neotectónico de la región del volcán Irazú, Costa Rica. Revista Geológica de America Central, 18: 25-42. https://doi.org/10.15517/rgac.v0i18.13522

Montero W., Lewis J.C., Marshall J.S., Kruse S. \& Wetmore P., 2013 - Neotectonic faulting and forearc sliver motion along the Atirro-Rio Sucio fault system, Costa Rica, Central America. Bulletin of the Geological Society of America, 125: 857-876.

https://doi.org/10.1130/B30471.1
Morse A.D., Lainez A. \& Howard K.T., 2011 - Exploration of lava tubes in the Teide National Park, a martian analog. In: First International Planetary Caves Workshop, Carlsbad, NM.

Morse J.W., Millero F.J., Cornwell J.C. \& Rickard D., 1987 - The chemistry of the hydrogen sulfide and iron sulfide systems in natural waters. Earth Science Reviews, 24: 1-42. https://doi.org/10.1016/0012-8252(87)90046-8

Mustard J.F., Murchie S.L., Pelkey S.M., Ehlmann B.L., Milliken R.E., Grant J.A., Bibring J.-P., Poulet F., Bishop J., Dobrea E.N., Roach L., Seelos F., Arvidson R.E., Wiseman S., Green R., Hash C., Humm D., Malaret E., McGovern J.A., Seelos K., Clancy T., Clark R., Marais D.D., Izenberg N., Knudson A., Langevin Y., Martin T., McGuire P., Morris R., Robinson M., Roush T., Smith M., Swayze G., Taylor H., Titus T. \& Wolff M., 2008 - Hydrated silicate minerals on Mars observed by the Mars Reconnaissance Orbiter CRISM instrument. Nature, 454: 305-309.

https://doi.org/10.1038/nature07097

Northup D.E., Hathaway J.J.M., Snider J.R., Moya M., Garcia M.G., Dapkevicius M.L.N.E., Riquelme C., Stone F.D., Spilde M.N. \& Boston P.J., 2012 - Life in earth's lava caves: Implications for life detection on other planets. In: Hanslmeier A., Kempe S. \& Seckbach J. (Eds.), Life on earth and other planetary bodies. Springer, New York, p. 459-484.

https://doi.org/10.1007/978-94-007-4966-5 26

Northup D.E., Melim L.A., Spilde M.N. \& Hathaway J.J.M., 2011 - Lava cave microbial communities within mats and secondary mineral deposits: implications for life detection on other planets. Astrobiology, 11: 1-18. https://doi.org/10.1089/ast.2010.0562

Onac, B.P. \& Forti, P., 2011a - State of the art and challenges in cave minerals studies. Studia UBB Geologia, 56: 33-42.

https://doi.org/10.5038/1937-8602.56.1.4

Onac B.P. \& Forti P., 2011b-Minerogenetic mechanisms occurring in the cave environment: An overview. International Journal of Speleology, 40: 79-98. https://doi.org/10.5038/1827-806X.40.2.1

Onac B.P., Sumrall J., Tămaş T., Povară I., Kearns J., Dârmiceanu V., Vereş D. \& Lascu C., 2009 - The relationship between cave minerals and $\mathrm{H}_{2} \mathrm{~S}$-rich thermal waters along the Cerna Valley (sw Romania). Acta Carsologica, 38: 27-39. https://doi.org/10.3986/ac.v38i1.135

Pierre D., Henley R.W., Opfergelt S. \& Detienne M., 2015 - Summit acid crater lakes and flank instability in composite volcanoes. In: Rouwet D., Christenson B., Tassi F. \& Vandemeulebrouc J. (Eds.), Volcanic lakes. Springer, Berlin, p. 289-305. https://doi.org/10.1007/978-3-642-36833-2_12

Protti M. \& Güendel F., 1995 - Correlation between the age of the subducting Cocos plate and the geometry of the Wadati-Benioff zone under Nicaragua and Costa Rica. In: Mann P. (Ed.), Geologic and tectonic development of the Caribbean plate boundary in Southern Central America. GeoScienceWorld, Boulder, Colorado, p. 309326. https://doi.org/10.1130/SPE295-p309

Ramírez R., Cordero C. \& Alvarado G.E., 2013 Variaciones y caracteristicas en los cambios de nivel de la laguna cretérica del volcán Irazú (1965-2012). Revista Geológica de America Central, 48: 141-157.

Riquelme C.G. \& Northup D.E., 2013 - Microbial ecology: Caves as an extreme habitat. In: Cheeptham N. (Ed.), Cave microbiomes: A novel resource for drug discovery. Springer, Kamloops, BC, Canada, p. 85-108. https://doi.org/10.1007/978-1-4614-5206-5 5 
Stoiber R.E. \& Rose W.I., 1974 - Fumarole incrustation at active Central American volcanoes. Geochemica et Cosmochimica Acta, 38: 495-516. https://doi.org/10.1016/0016-7037(74)90037-4

Thollot P., Mangold N., Ansan V., Le Mouélic S., Milliken R.E., Bishop J.L., Weitz C.M., Roach L.H., Mustard J.F. \& Murchie S.L., 2012 - Most Mars minerals in a nutshell: Various alteration phases formed in a single environment in Noctis Labyrinthus. Journal of
Geophysical Research Planets, 117: 1-28.

https://doi.org/10.1029/2011JE004028

Ulloa A., Campos-Fernández C.S. \& Rojas L., 2013 - Cueva los Minerales, Volcán Irazú, Costa Rica: descripción, mineralogía y origen. Revista Geológica de America Central, 48: 169-187.

Ulloa A., Haydock A., Trescott S., 2015 - Explorations in the caves of Irazú Volcano and their amazing minerals. NSS News, 73: 4-11. 